\title{
A critical review of oxazolidinones: An alternative or replacement for glycopeptides and streptogramins?
}

\author{
George G Zhanel PhD ${ }^{1-4}$, Coleen Schroeder $\mathrm{BSc}^{2}$, Lavern Vercaigne PharmD ${ }^{2}$, Alfred S Gin PharmD ${ }^{2}$, \\ John Embil MD ${ }^{1,4}$, Daryl J Hoban PhD ${ }^{1,3}$
}

GG Zhanel, C Schroeder, L Vercaigne, AS Gin, J Embil, DJ Hoban. A critical review of oxazolidinones: An alternative or replacement for glycopeptides and streptogramins? Can J Infect Dis 2001;12(6):379-390.

OBJECTIVE: To review the available data on the oxazolidinones linezolid and eperezolid.

DATA SELECTION: Published reports were obtained by searching MEDLINE for articles published between 1992 and 2000 , inclusive. References of published papers were also obtained and reviewed. Abstracts from scientific proceedings were reviewed.

DATA EXTRACTION: Due to the limited data available regarding these agents, the criteria for study inclusion were not restrictive.

DATA SYNTHESIS: The oxazolidinones (eg, linezolid) are a new antimicrobial class with a unique mechanism of action. They are active against resistant Gram-positive cocci including methicillin-susceptible and -resistant Staphylococcus aureus (MRSA), methicillin-susceptible and -resistant Staphylococccus epidermidis, vancomycin-resistant enterococci (VRE) and penicillin-resistant Streptococcus pneumoniae (PRSP). Linezolid is active against anaerobes and displays modest activity against fastidious Gram-negative pathogens such as Haemophilus influenzae, but is not active against Enterobacteriaceae. Linezolid is available both orally and parenterally, and has a bioavailability of $100 \%$. Clinical trials comparing linezolid with standard therapy have demonstrated similar bacteriological and clinical cures rates to standard therapy in community- and hospital-acquired pneumonia, uncomplicated and complicated skin and soft tissue infections, and infections caused by MRSA and VRE. Adverse effects have been minor and infrequent; however, platelets should be monitored in patients who have received more than two weeks of linezolid therapy. It is expected that these agents will have a bright future due to their excellent spectrum of activity against antibiotic-resistant Gram-positive organisms, such as MRSA, VRE and PRSP, and their excellent bioavailability.

CONCLUSION: The oxazolidinones represent a new class of antimicrobials with a unique mechanism of action. They have excellent activity against susceptible and resistant Gram-positive organisms such as MRSA, methicillin-susceptible $S$ epidermidis, VRE and PRSP, and a good adverse effect profile; they can be administered both intravenously and orally. Their potential use in Canada may be as an intravenous and oral alternative to glycopeptides and streptogramins.

Key Words: Glycopeptides; Linezolid; Oxzolidinones; Streptogramins

\section{Revue critique des oxazolidinones : Comme solution de rechange ou substitution aux glycopeptides et streptogramines?}

OBJECTIF : Passer en revue les données actuelles sur les oxazolidinones linézolide et épérézolide. SÉLECTION DES DONNÉES : Une interrogation du réseau MEDLINE a permis d'obtenir des articles parus entre 1992 et 2000, inclusivement. Les références des articles publiés ont également été passées en revue. Les comptes-rendus de réunions scientifiques ont aussi été examinés.

Voir page suivante

\footnotetext{
${ }^{1}$ Department of Medical Microbiology, and ${ }^{2}$ Faculties of Medicine and Pharmacy, University of Manitoba; Departments of ${ }^{3}$ Clinical Microbiology and ${ }^{4}$ Medicine, Health Sciences Centre, Winnipeg, Manitoba

Correspondence and reprints: Dr George G Zhanel, Microbiology, Health Sciences Centre, MS673 - 820 Sherbrook Street, Winnipeg, Manitoba R3A 1R9. Telephone 204-787-4902, fax 204-787-4699, e-mail ggzhanel@pcs.mb.ca
} 
EXTRACTION DES DONNÉES : En raison du nombre limité de données disponibles au sujet de ces agents, les critères d'inclusion des études n'ont pas été restrictifs.

SYNTHÈSE DES DONNÉES : Les oxazolidinones (p. ex., linézolide) constituent une nouvelle classe d'antimicrobiens dotés d'un mode d'action unique. Ils agissent contre les germes Gram positifs résistants, notamment le staphylocoque doré méthicillino-sensible et méthicillino-résistant, le Staphylococcus epidermidis méthicillino-sensible et méthicillino-résistant, les entérocoques vancomycine-résistants et le Streptococcus pneumonice pénicillino-résistant. Le linézolide agit contre les anaérobies et manifeste une activité modeste contre les agents pathogènes Gram négatifs fastidieux, comme Homophilus influenza, mais il n'agit pas contre les entérobactéries. Le linézolide est offert sous forme orale et sous forme parentérale et il est doté d'une biodisponibilité de $100 \%$. Les essais cliniques comparant le linézolide et le traitement standard ont fait état de taux de guérison bactériologique et clinique comparables dans le traitement de la pneumonie hospitalière et extra-hospitalière, des infections de la peau et des tissus mous non compliquées et compliquées et dans les infections causées par Staphylococcus aureus méthicillino-résistant et les entérocoques vancomycine-résistants. Les réactions indésirables ont été bénignes et rares. Par contre, les plaquettes sont à surveiller chez les patients qui ont reçu plus de deux semaines de traitement par linézolide. On s'attend à ce que ces agents aient un avenir prometteur en raison de leur excellent spectre d'activité contre les agents pathogènes Gram positifs résistant aux antibiotiques, comme le Staphylococcus aureus méthicillino-résistant, les entérocoques vancomycine-résistants et le Streptococcus pneumonice pénicillino-résistant, et en raison de leur excellente biodisponibilité.

CONCLUSIONS : Les oxazolidinones représentent une nouvelle classe d'antibiotiques dotés d'un mode d'action unique. Ils exercent une excellente activité contre des agents Gram positifs sensibles et résistants, comme les souches de Staphylococcus aureus méthicillino-résistantes, de $S$. epidermidis méthicillino-sensibles, les entérocoques vancomycinerésistants et le Streptococcus pneumonioe pénicillino-résistant; ils sont en outre dotés d'un bon profil d'innocuité. Ils peuvent être administrés par voie intraveineuse et par voie orale. Leur utilisation potentielle au Canada pourrait représenter une solution de rechange avantageuse par voie intraveineuse et orale par rapport aux glycopeptides et aux streptogramines.

$\mathrm{O}$ xazolidinones are the first new class of antibiotics to be developed in the past 20 years. In 1978, EI DuPont de Nemours \& Company originally discovered that certain oxazolidinones had activity against plant pathogens but limited activity against human pathogens (1). Further development of this class in the late 1980s occurred with the description of DuP-721 and DuP-105, which had activity against human pathogens (2). The discovery of lethal bone marrow toxicity in drug safety studies performed in rats led to the termination of development (3-5). Observing the potential for this new class of synthetic antibacterial agents, Pharmacia \& Upjohn began development and patented many chemical oxazolidinone congeners (6). Oxazolidinones demonstrate a novel mechanism of action by inhibiting the initiation of protein synthesis at a site different from other protein synthesis inhibitors (7). Currently, there are only two oxazolidinones: linezolid (oral and intravenous), which has just recently been licensed in the United States and is now available in Canada, and eperezolid (6). The chemical structures of these two agents differ slightly from the original compounds, with differences in their side chains on the benzene ring and the addition of a fluorine atom $(6,8)$. Oxazolidinones have activity against many antibiotic-resistant organisms (mostly Gram-positives), even those cross-resistant to other protein synthesis inhibitors $(2,7)$. Manipulation of the chemical structure continues to broaden the spectrum of activity and to reduce or eliminate adverse effects. The present review describes in detail the chemistry, mechanisms of action and resistance, in vitro and in vivo activity, pharmacokinetics, pharmacodynamics, adverse effects and drug interactions of the oxazolidinones. Only linezolid, also known as PNU-100766 and U-100766, and eperezolid, also known as PNU-100592 and U-100592, are reviewed in the present article (Figure 1).

\section{CHEMISTRY}

The oxazolidinone nucleus has many pharmaceutical uses, among these is its antimicrobial activity. Oxazolidinones are synthetic molecules, and the first agents that were developed, DuP-721 and DuP-105, caused bone marrow toxicity (3$5)$. Figure 2 displays the basic chemical structures of oxazolidinones, indicating the $\mathrm{A}$ and $\mathrm{B}$ positions. In vitro structure and activity relationships (SAR) have been extensively studied (6). The SAR between the A and B positions are of importance for antimicrobial activity. It has been reported that the acetamide group at the $\mathrm{B}$ position has the most potent antimicrobial activity (8). Antimicrobial activity is only evident in the 5S-acetamidomethyl enantiomer (Figure 2). Alteration of the B group significantly decreased the antimicrobial activity (8).

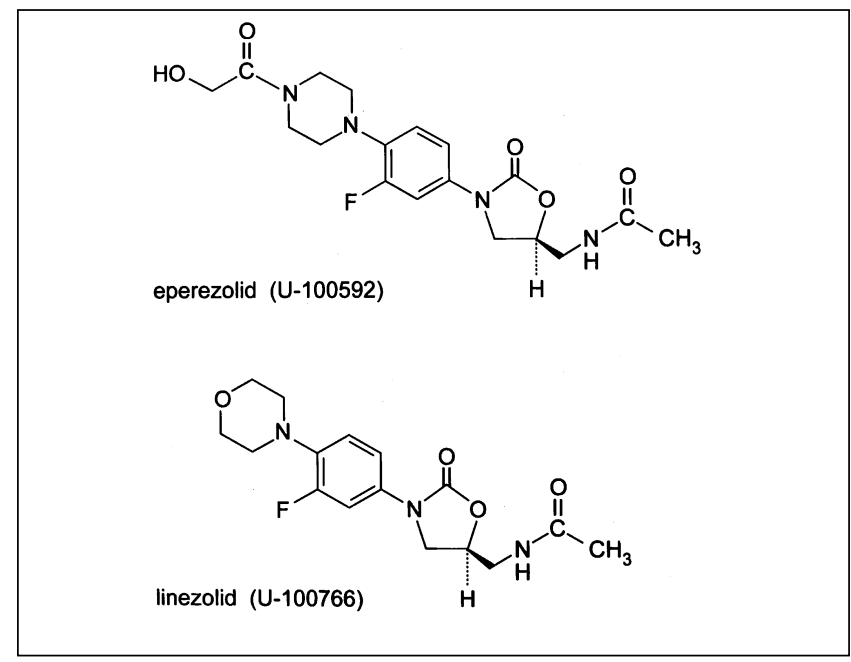

Figure 1) Chemical structure of eperezolid and linezolid 


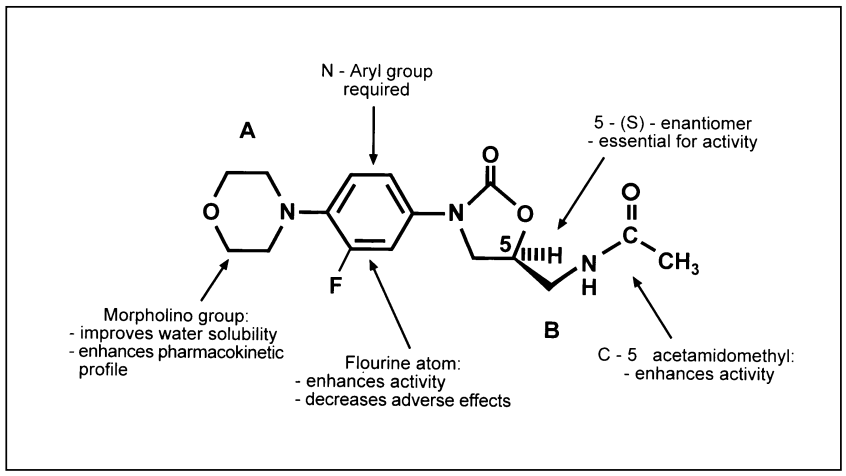

Figure 2) Structure activity relationships of linezolid

In vivo studies reported that modification of the chemical structure at the A position and the addition of a fluorine substituent on the phenyl 3-position eliminated the toxic bone marrow effects, decreased adverse reactions and enhanced activity (6). The size of the 3-substituents is very important; the larger the substituent, the less antimicrobial activity $(9,10)$. Altering the spectrum of activity of the oxazolidinones to include greater activity against Haemophilus influenzae, Moraxella catarrhalis and other Gram-negative organisms is an area of research currently underway (11-13). Several derivatives have been described that are more potent in vitro than linezolid, eperezolid and vancomycin (13). The description of pyrrolylphenyl (PNU-171933) and pyrazolylphenyl (PNU172576) oxazolidinones has recently been made by Pharmacia \& Upjohn (USA) (13). These agents demonstrated activity several times more potent than vancomycin against both Grampositive and Gram-negative bacteria (13).

\section{MECHANISMS OF ACTION}

Oxazolidinone antimicrobials have a novel mechanism of action. These antimicrobials bind to the $50 \mathrm{~S}$ ribosomal subunit and inhibit the initiation of protein synthesis (Figure 3) $(7,14,15)$. The prokaryotic process for protein synthesis is described below, with a specific focus on where and how oxazolidinones inhibit this process (Figure 3).

The ribosomes of prokaryotic cells consists of two subunits, the $30 \mathrm{~S}$ and the 50S. The 30S subunit contains 16S rRNA and 21 polypeptide chains, and the $50 \mathrm{~S}$ subunit consists of $5 \mathrm{~S}$ and $23 \mathrm{~S}$ rRNA and 34 polypeptide chains (16). Protein synthesis is carried out in three distinct steps - initiation, elongation and termination (Figure 3). The messenger RNA (mRNA) is transcribed and released for translation within the cell (16). The translation process begins with initiation factors attaching to the $30 \mathrm{~S}$ subunit along with the mRNA and the initiator transfer RNA (tRNA)-N-formylmethionine (fMet) (16). The 50S rRNA subunit is then attached and completes 70 S the initiation complex. This ternary initiation complex with the fMet positioned at the peptidyl site (P site) allows for protein synthesis to be initiated. The mRNA is then translated with specific amino acids attached to specific tRNA, which enables the individual amino acids to be sequenced correctly for the specific protein. Next, elongation proceeds and allows the

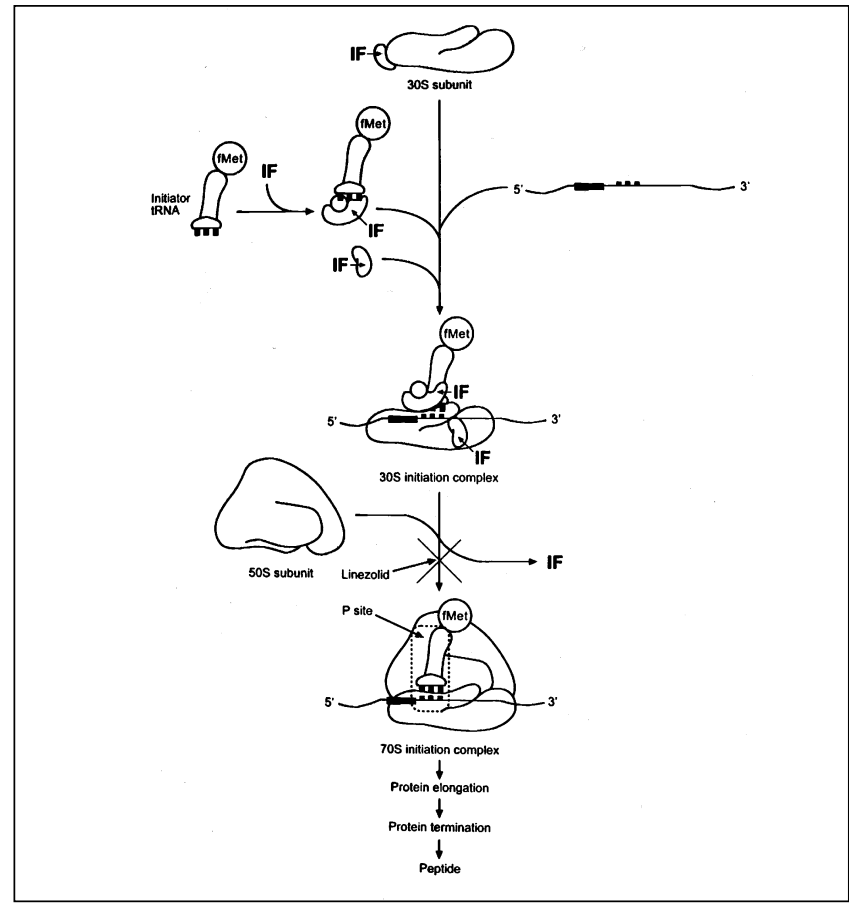

Figure 3) Mechanism of action of oxazolidinones: Inhibition of the protein synthesis initiation complex

protein to elongate. Once completed, the protein is terminated and the mature peptide is released (16).

While it was discovered early on that oxazolidinones inhibited protein synthesis, the exact site was unclear $(14,17)$. Inhibition of protein elongation was eliminated as a mechanism of action by comparing antimicrobial activities with and without chloramphenicol (15). Chloramphenicol inhibits protein synthesis by inhibiting peptidyl transferase, an important enzyme in protein elongation $(18,19)$. Investigators also established that oxazolidinones did not interfere with the protein termination process, and thus, inhibition of protein synthesis initiation was the probable mechanism (15).

Because of their novel mechanism of action of inhibiting protein synthesis, cross-resistance between oxazolidinones and other protein synthesis inhibiting antimicrobials has not been reported $(20,21)$. In a recent study by Matassova et al (17), investigators using both ultraviolet-induced cross-linking and chemical foot-printing concluded that oxazolidinones inhibit elongation by affecting the translocation step of protein synthesis. In this system, they did not find any effects on initiation or on the transition phase from initiation to elongation (17). From the results of this study, it appears that the mechanism of action of oxazolidinone antimicrobials has yet to be conclusively discerned.

\section{MECHANISMS OF RESISTANCE}

Being a new antimicrobials class, it is not that surprising that resistance in clinical strains of Staphylococcus species and Streptococcus species has not yet been reported. However, two cases of linezolid-resistant Enterococcus faecium have recently been reported during the compassionate use program (22). Both patients had infected, nonremovable 
TABLE 1

In vitro activity of oxazolidinones vancomycin and quinupristin/dalfopristin (Q/D) against Gram-positive aerobes

\begin{tabular}{|c|c|c|c|c|c|c|c|c|c|c|c|c|}
\hline \multirow[b]{2}{*}{ Bacteria } & \multicolumn{9}{|c|}{ Oxazolidinones } & \multicolumn{3}{|c|}{$Q / D$} \\
\hline & $\mathrm{MIC}_{50}$ & $\mathrm{MIC}_{90}$ & Range & $\mathrm{MIC}_{50} \Lambda$ & $\mathrm{AIC}_{90}$ & Range & $\mathrm{MIC}_{50}$ & $\mathrm{MIC}_{90}$ & Range & $\mathrm{MIC}_{50}$ & $\mathrm{MIC}_{90}$ & Range \\
\hline Staphylococcus aureus & 1 & 2 & $0.5-4.0$ & 2 & 4 & $0.5-8.0$ & 1 & 2 & $0.03-12$ & 0.5 & 1 & $0.016-4$ \\
\hline$S$ aureus (MS) & 1 & 2 & $1.0-4.0$ & 4 & 4 & $2.0-8.0$ & 0.5 & 1 & $0.25-1.0$ & 0.25 & 0.5 & $0.016-1$ \\
\hline$S$ aureus (MR) & 1 & 2 & $1.0-4.0$ & 2 & 2 & $1.0-4.0$ & 1 & 2 & $0.03-12$ & 0.5 & 1 & $0.125-32$ \\
\hline Staphylococcus epidermidis & 0.5 & 1 & $0.25-2.0$ & $\mathrm{~N} / \mathrm{A}$ & $\mathrm{N} / \mathrm{A}$ & $\mathrm{N} / \mathrm{A}$ & 1 & 2 & $1-4$ & 0.25 & 0.5 & $0.03-16$ \\
\hline S epidermidis (MS) & 1 & 2 & $0.5-2.0$ & 1 & 1 & $0.5-1.0$ & 2 & 2 & $1-2$ & 0.25 & 0.5 & $0.03-1$ \\
\hline$S$ epidermidis (MR) & 1 & 2 & $0.5-2.0$ & 1 & 1 & $0.5-1.0$ & 2 & 4 & $1-4$ & 0.25 & 0.5 & $0.06-4$ \\
\hline Staphylococcus saprophyticus & 4 & $\mathrm{~N} / \mathrm{A}$ & $\mathrm{N} / \mathrm{A}$ & 4 & $\mathrm{~N} / \mathrm{A}$ & N/A & 2 & 4 & $1.0-4.0$ & 0.5 & 1 & $0.12-4$ \\
\hline $\begin{array}{l}\text { Streptococcus pyogenes } \\
\text { (group A) }\end{array}$ & 1 & 2 & $1.0-2.0$ & 1 & 1 & $0.5-1.0$ & 0.5 & 1 & $0.5-1$ & 0.06 & 0.25 & $0.06-2$ \\
\hline $\begin{array}{l}\text { Streptococcus agalactiae } \\
\text { (group B) }\end{array}$ & 1 & 2 & $0.5-2.0$ & 0.5 & 1 & $0.5-1.0$ & 0.5 & 0.5 & $0.03-2$ & 0.5 & 1 & $0.03-32$ \\
\hline Streptococcus species (group C) & 2 & 2 & $1-2$ & $\mathrm{~N} / \mathrm{A}$ & $\mathrm{N} / \mathrm{A}$ & $\mathrm{N} / \mathrm{A}$ & 0.5 & 1 & $0.03-2$ & 0.5 & 1 & $0.06-4$ \\
\hline Streptococcus species (group G) & 2 & 2 & $1-4$ & $\mathrm{~N} / \mathrm{A}$ & $\mathrm{N} / \mathrm{A}$ & $\mathrm{N} / \mathrm{A}$ & 0.5 & 1 & $0.03-1$ & 0.5 & 1 & $0.06-4$ \\
\hline Streptococcus species (group F) & 2 & 2 & $1-2$ & $\mathrm{~N} / \mathrm{A}$ & $\mathrm{N} / \mathrm{A}$ & $\mathrm{N} / \mathrm{A}$ & 0.5 & 1 & $0.03-1$ & 0.5 & 1 & $0.06-4$ \\
\hline Streptococcus pneumoniae & 0.5 & 1 & $0.06-4$ & 1 & 1 & $0.5-1.0$ & 0.25 & 1 & $0.06-1$ & 0.25 & 0.5 & \\
\hline S pneumoniae (PS) & 0.5 & 1 & $0.06-4$ & 0.5 & 0.5 & $0.25-1.0$ & 0.25 & 0.25 & $0.06-0.5$ & 0.25 & 0.5 & $0.008-4$ \\
\hline S pneumoniae (PI) & 0.5 & 1 & $0.06-2$ & 0.25 & 0.25 & $0.06-1.0$ & 0.5 & 1 & $0.25-1$ & 0.25 & 0.5 & $0.08-4$ \\
\hline S pneumoniae (PR) & 1 & 1 & $0.06-4$ & 0.25 & 0.5 & $0.125-1$ & 0.5 & 1 & $0.25-1$ & 0.25 & 0.5 & $0.08-4$ \\
\hline Enterococcus faecalis & 1 & 1 & $0.5-2.0$ & 1 & 1 & $0.5-2.0$ & 1 & 2 & $1.0-4.0$ & 8 & 16 & $0.5-32$ \\
\hline E faecalis (VS) & 1 & 2 & $1.0-4.0$ & 2 & 2 & $1.0-4.0$ & 1 & 2 & $1-2$ & 8 & 16 & $0.5-32$ \\
\hline E faecalis (VR) & 1 & 2 & $1.0-4.0$ & 1 & 2 & $0.5-2.0$ & $\mathrm{~N} / \mathrm{A}$ & $\mathrm{N} / \mathrm{A}$ & $\mathrm{N} / \mathrm{A}$ & 8 & 16 & $0.5-32$ \\
\hline E faecalis (vanB) & 1 & 2 & $2.0-4.0$ & 2 & 2 & $1.0-4.0$ & $\mathrm{~N} / \mathrm{A}$ & $\mathrm{N} / \mathrm{A}$ & $\mathrm{N} / \mathrm{A}$ & 8 & 16 & $0.5-32$ \\
\hline Enterococcus faecium & 1 & 2 & $0.5-4.0$ & 1 & 1 & $0.5-4.0$ & $\mathrm{~N} / \mathrm{A}$ & $\mathrm{N} / \mathrm{A}$ & $\mathrm{N} / \mathrm{A}$ & 0.5 & 1 & $0.06-16$ \\
\hline E faecium (VS) & 2 & 2 & $1.0-2.0$ & 1 & 2 & $1.0-2.0$ & $\mathrm{~N} / \mathrm{A}$ & $\mathrm{N} / \mathrm{A}$ & $\mathrm{N} / \mathrm{A}$ & 0.5 & 1 & $0.06-16$ \\
\hline E faecium (VR) & 1 & 2 & $0.5-2.0$ & 1 & 1 & $0.5-2.0$ & $\mathrm{~N} / \mathrm{A}$ & $\mathrm{N} / \mathrm{A}$ & $\mathrm{N} / \mathrm{A}$ & 0.5 & 1 & $0.06-16$ \\
\hline E faecium (VanA) & 2 & 2 & $1.0-4.0$ & 2 & 2 & $0.5-4.0$ & $\mathrm{~N} / \mathrm{A}$ & $\mathrm{N} / \mathrm{A}$ & $\mathrm{N} / \mathrm{A}$ & 0.5 & 1 & $0.06-16$ \\
\hline E faecium (VanB) & 1 & 2 & $1.0-4.0$ & 2 & 2 & $1.0-4.0$ & $\mathrm{~N} / \mathrm{A}$ & $\mathrm{N} / \mathrm{A}$ & $\mathrm{N} / \mathrm{A}$ & 0.5 & 1 & $0.06-16$ \\
\hline Listeria moncytogenes & 2 & 2 & $2.0-4.0$ & 4 & 8 & $4.0-8.0$ & 1 & 1 & $0.5-2$ & 0.25 & 1 & $0.125-2$ \\
\hline
\end{tabular}

$\mathrm{MIC}_{50}$ Minimum inhibitory concentration $(\mu \mathrm{g} / \mathrm{mL})$ of $50 \%$ of isolates; $\mathrm{MIC}_{90}$ Minimum inhibitory concentration $(\mu \mathrm{g} / \mathrm{mL})$ of $90 \%$ of isolates;

MR Methicillin resistant; MS Methicillin susceptible; N/A Information not available; PS Penicillin susceptible (MIC $\leq 0.06 \mu \mathrm{gg} / \mathrm{mL}$; PI Penicillin intermediate (MIC 0.12 to $1.0 \mu \mathrm{g} / \mathrm{mL}$ ); PR Penicillin resistant (MIC $\geq 2 \mathrm{~g} / \mathrm{mL}$ ); VS Vancomycin susceptible (MIC $\leq 4 \mu \mathrm{g} / \mathrm{mL}$ ); VR Vancomycin resistant (MIC $\geq \mu \mathrm{g} / \mathrm{mL}$ ).

Adapted from references 2,21,23,25-41

internal devices with concomitant bacteremia. The patients had received more than four weeks of parenteral linezolid therapy, consisting of $600 \mathrm{mg}$ twice daily. Cultures were obtained at various intervals to assess the antimicrobial susceptibility (using standard methods) and the genetic mutations in the 23S rRNA (using sequence analysis) (22). The results were as follows: the initial minimum inhibitory concentrations (MIC) for both isolates were $2 \mu \mathrm{g} / \mathrm{mL}$, and the final MICs were $16 \mu \mathrm{g} / \mathrm{mL}$ (eightfold increase) and $32 \mu \mathrm{g} / \mathrm{mL}$ (16-fold increase). The 23S rRNA from these resistant strains of E faecium were analyzed and found to contain a G2657U transversion. At this position, a uracil (pyrimidine) replaced a guanine (purine) (22). The greater the number of 23S rRNA mutations present in the organism, the greater the degree of linezolid resistance (22).

These results are consistent with data obtained in laboratory mutants $(21,23)$. Although creating oxazolidinoneresistant mutants has been difficult (frequency $1 \times 10^{-9}$ to $\left.1 \times 10^{-11}\right)$, Staphylococcus aureus- and E faecalis-resistant strains have been created using a spiral-gradient method $(20,21,23)$. The low mutation frequency to obtain resistant organisms to linezolid is encouraging for the prediction of future clinical use.

A recent study created laboratory-derived linezolid resistant mutants using Halobacterium halobium, a halophilic archeon, because it has only one copy of 23S rRNA (24). All of the linezolid mutants had a single point mutation in the 23S rRNA molecule. The mutations were C2452U, U2500C, A2453G and U2504C, among which the U2500C mutation was associated with the largest degree of linezolid resistance (24). All six mutations clustered around the peptidyl transferase centre (domain V). However, oxazolidinones do not inhibit peptidyl transferase as other antimicrobials that also bind at this site do (24).

\section{MICROBIOLOGY}

The in vitro activities of oxazolidinones against clinically important bacterial species are compared with vancomycin and quinupristin/dalfopristin in Tables 1 to $4(2,21,23,25$ 39). The tables present the minimum concentrations of antibiotic necessary to inhibit the growth of $50 \%$ of isolates $\left(\mathrm{MIC}_{50}\right)$ and $90 \%$ of isolates $\left(\mathrm{MIC}_{90}\right)$. The MIC values represent 
TABLE 2

In vitro activity of oxazolidinones vancomycin and quinupristin/dalfopristin (Q/D) against gram-negative aerobes

\begin{tabular}{|c|c|c|c|c|c|c|c|c|c|c|c|c|}
\hline \multirow[b]{3}{*}{ Bacteria } & \multicolumn{6}{|c|}{ Oxazolidinones } & \multirow{2}{*}{\multicolumn{3}{|c|}{ Vancomycin }} & \multirow{2}{*}{\multicolumn{3}{|c|}{ Q/D }} \\
\hline & \multicolumn{3}{|c|}{ Linezolid } & \multicolumn{3}{|c|}{ Eperezolid } & & & & & & \\
\hline & $\mathrm{MIC}_{50}$ & $\mathrm{MIC}_{90}$ & Range & $\mathrm{MIC}_{50}$ & $\mathrm{MIC}_{90}$ & Range & $\mathrm{MIC}_{50}$ & $\mathrm{MIC}_{90}$ & Range & $\mathrm{MIC}^{50}$ & $\mathrm{MIC}_{90}$ & Range \\
\hline Escherichia coli & $>64$ & $>64$ & $\mathrm{~N} / \mathrm{A}$ & $\mathrm{N} / \mathrm{A}$ & $\mathrm{N} / \mathrm{A}$ & $\mathrm{N} / \mathrm{A}$ & $\mathrm{N} / \mathrm{A}$ & $\mathrm{N} / \mathrm{A}$ & $\mathrm{N} / \mathrm{A}$ & $\mathrm{N} / \mathrm{A}$ & $\mathrm{N} / \mathrm{A}$ & $\mathrm{N} / \mathrm{A}$ \\
\hline Haemophilus influenzae & 8 & 16 & $4.0-16$ & 8 & 8 & $4.0-8.0$ & $\mathrm{~N} / \mathrm{A}$ & $\mathrm{N} / \mathrm{A}$ & $\mathrm{N} / \mathrm{A}$ & 2 & 4 & $1-32$ \\
\hline Klebsiella pneumoniae & $>64$ & $>64$ & $\mathrm{~N} / \mathrm{A}$ & $\mathrm{N} / \mathrm{A}$ & $\mathrm{N} / \mathrm{A}$ & $\mathrm{N} / \mathrm{A}$ & $\mathrm{N} / \mathrm{A}$ & $N / A$ & $\mathrm{~N} / \mathrm{A}$ & $\mathrm{N} / \mathrm{A}$ & $\mathrm{N} / \mathrm{A}$ & $\mathrm{N} / \mathrm{A}$ \\
\hline Moraxella catarrhalis & 2 & 4 & $2.0-8.0$ & 4 & 4 & $2.0-4.0$ & $\mathrm{~N} / \mathrm{A}$ & $\mathrm{N} / \mathrm{A}$ & $\mathrm{N} / \mathrm{A}$ & 0.25 & 0.5 & $0.016-8$ \\
\hline Mycobacterium tuberculosis & $\mathrm{N} / \mathrm{A}$ & $\mathrm{N} / \mathrm{A}$ & $\mathrm{N} / \mathrm{A}$ & $\mathrm{N} / \mathrm{A}$ & $\mathrm{N} / \mathrm{A}$ & $\mathrm{N} / \mathrm{A}$ & $\mathrm{N} / \mathrm{A}$ & $\mathrm{N} / \mathrm{A}$ & $\mathrm{N} / \mathrm{A}$ & $\mathrm{N} / \mathrm{A}$ & $\mathrm{N} / \mathrm{A}$ & $\mathrm{N} / \mathrm{A}$ \\
\hline Mycobacterium avium complex & $\mathrm{N} / \mathrm{A}$ & $\mathrm{N} / \mathrm{A}$ & $\mathrm{N} / \mathrm{A}$ & $\mathrm{N} / \mathrm{A}$ & $\mathrm{N} / \mathrm{A}$ & $\mathrm{N} / \mathrm{A}$ & $\mathrm{N} / \mathrm{A}$ & $\mathrm{N} / \mathrm{A}$ & $\mathrm{N} / \mathrm{A}$ & $\mathrm{N} / \mathrm{A}$ & $\mathrm{N} / \mathrm{A}$ & $\mathrm{N} / \mathrm{A}$ \\
\hline Proteus vulgaris & $>64$ & $>64$ & $\mathrm{~N} / \mathrm{A}$ & $\mathrm{N} / \mathrm{A}$ & $\mathrm{N} / \mathrm{A}$ & $\mathrm{N} / \mathrm{A}$ & $\mathrm{N} / \mathrm{A}$ & $\mathrm{N} / \mathrm{A}$ & $\mathrm{N} / \mathrm{A}$ & $\mathrm{N} / \mathrm{A}$ & $\mathrm{N} / \mathrm{A}$ & $\mathrm{N} / \mathrm{A}$ \\
\hline
\end{tabular}

$\mathrm{MIC}_{50}$ Minimum inhibitory concentration $(\mu \mathrm{g} / \mathrm{mL})$ of $50 \%$ of isolates; $\mathrm{MIC}_{90}$ Minimum inhibitory concentration $(\mu \mathrm{g} / \mathrm{mL})$ of $90 \%$ of isolates;

N/A Information not available. Adapted from references 2,21,25,33,36,36-42

TABLE 3

In vitro activity of oxazolidinones vancomycin and quinupristin/dalfopristin (Q/D) against anaerobes

\begin{tabular}{|c|c|c|c|c|c|c|c|c|c|c|c|c|}
\hline \multirow[b]{3}{*}{ Bacteria } & \multirow[b]{3}{*}{$\mathrm{MIC}_{50}$} & \multicolumn{4}{|c|}{ Oxazolidinones } & \multirow[b]{3}{*}{ Range } & \multirow{2}{*}{\multicolumn{3}{|c|}{ Vancomycin }} & \multirow{2}{*}{\multicolumn{2}{|c|}{ Q/D }} & \multirow[b]{3}{*}{ Range } \\
\hline & & \multicolumn{2}{|c|}{ Linezolid } & \multicolumn{2}{|c|}{ Eperezolid } & & & & & & & \\
\hline & & $\mathrm{MIC}_{90}$ & Range & $\mathrm{MIC}_{50}$ & $\mathrm{MIC}_{90}$ & & $\mathrm{MIC}_{50}$ & $\mathrm{MIC}_{90}$ & Range & $\mathrm{MIC}_{50}$ & $\mathrm{MIC}_{90}$ & \\
\hline Bacteroides fragilis & 4 & 4 & $0.5-8.0$ & 8 & 16 & $4-16$ & $\mathrm{~N} / \mathrm{A}$ & $\mathrm{N} / \mathrm{A}$ & $4.0-8.0$ & 2 & 16 & $1.0-16$ \\
\hline Clostridium difficile & 2 & 8 & $2-8$ & $\mathrm{~N} / \mathrm{A}$ & $\mathrm{N} / \mathrm{A}$ & $\mathrm{N} / \mathrm{A}$ & 1 & 2 & $0.5-4$ & $\mathrm{~N} / \mathrm{A}$ & N/A & $\mathrm{N} / \mathrm{A}$ \\
\hline Clostridium perfringens & 2 & 2 & $0.5-2.0$ & 2 & $\mathrm{~N} / \mathrm{A}$ & $\mathrm{N} / \mathrm{A}$ & 0.5 & 1 & $0.25-1$ & 0.25 & 1 & $\mathrm{~N} / \mathrm{A}$ \\
\hline Fusobacterium species & 0.5 & 0.5 & $0.125-1.0$ & 0.5 & $\mathrm{~N} / \mathrm{A}$ & $\mathrm{N} / \mathrm{A}$ & 0.5 & 1 & $0.5-1.0$ & $\mathrm{~N} / \mathrm{A}$ & $\mathrm{N} / \mathrm{A}$ & N/A \\
\hline Peptostreptococcus species & 1 & 2 & $0.5-2.0$ & 1 & 1 & $0.5-1.0$ & 0.5 & 1 & $0.25-1.0$ & 0.25 & 1 & $\mathrm{~N} / \mathrm{A}$ \\
\hline
\end{tabular}

$\mathrm{MIC}_{50}$ Minimum inhibitory concentration $(\mu \mathrm{g} / \mathrm{mL})$ of $50 \%$ of isolates; $\mathrm{MIC}_{90}$ Mininmum inhibitory concentration $(\mu \mathrm{g} / \mathrm{mL})$ of $90 \%$ of isolates;

N/A Information not available. Adapted from references 2,21,25,27,33,35,36,37-40

\section{TABLE 4}

In vitro activity of oxazolidinones, vancomycin and quinupristin/dalfopristin (Q/D) against miscellaneous bacteria

\begin{tabular}{|c|c|c|c|c|c|c|c|c|c|c|c|c|}
\hline \multirow[b]{3}{*}{ Bacteria } & \multicolumn{6}{|c|}{ Oxazolidinones } & \multirow{2}{*}{\multicolumn{3}{|c|}{ Vancomycin }} & \multirow{2}{*}{\multicolumn{3}{|c|}{ Q/D }} \\
\hline & \multicolumn{3}{|c|}{ Linezolid } & \multicolumn{3}{|c|}{ Eperezolid } & & & & & & \\
\hline & $\mathrm{MIC}_{50}$ & $\mathrm{MIC}_{90}$ & Range & $\mathrm{MIC}_{50}$ & $\mathrm{MIC}_{90}$ & Range & $\mathrm{MIC}_{50}$ & $\mathrm{MIC}_{90}$ & Range & $\mathrm{MIC}_{50}$ & $\mathrm{MIC}_{90}$ & Range \\
\hline Legionella species & 2 & 4 & $1.0-4.0$ & 1 & 4 & $1.0-8.0$ & $\mathrm{~N} / \mathrm{A}$ & $\mathrm{N} / \mathrm{A}$ & N/A & $0.5-1$ & 1 & $0.25-2$ \\
\hline Neisseria gonorrhoeae & 8 & 16 & $2.0->16$ & 8 & $>16$ & $2.0->16$ & $\mathrm{~N} / \mathrm{A}$ & $\mathrm{N} / \mathrm{A}$ & $\mathrm{N} / \mathrm{A}$ & 0.25 & 0.5 & $0.016-2$ \\
\hline Pasteurella species & 2 & 2 & 1.0-8.0 & $\mathrm{N} / \mathrm{A}$ & $\mathrm{N} / \mathrm{A}$ & $\mathrm{N} / \mathrm{A}$ & $\mathrm{N} / \mathrm{A}$ & $\mathrm{N} / \mathrm{A}$ & $\mathrm{N} / \mathrm{A}$ & $\mathrm{N} / \mathrm{A}$ & $\mathrm{N} / \mathrm{A}$ & $\mathrm{N} / \mathrm{A}$ \\
\hline
\end{tabular}

$\mathrm{MIC}_{50}$ Minimum inhibitory concentration $(\mu \mathrm{g} / \mathrm{mL})$ of $50 \%$ of isolates; $\mathrm{MIC}_{90}$ Minimum inhibitory concentration $(\mu \mathrm{g} / \mathrm{mL})$ of $90 \%$ of isolates; $\mathrm{N} / \mathrm{A}$ Information not available. Adapted from references 25,36,37-41,43

the commonly occurring values reported in the literature examined for each drug. Data obtained were not restricted to growth conditions (including growth media) or the method used to carry out the study.

Bacteriostatic agents inhibit the growth or multiplication of the bacteria while a bactericidal agent kills $3 \log _{10}$ growth or greater over $24 \mathrm{~h}$ (40). Oxazolidinones are generally considered to be bacteriostatic; however, they are considered to bactericidal against Streptococcus pneumoniae (25).

Table 1 shows the in vitro activity of the oxazolidinones as well as vancomycin and quinupristin/dalfopristin against Gram-positive aerobes $(2,21,23,25-41)$. Linezolid has activity against $S$ aureus and Staphylococcus epidermidis, including methicillin-susceptible (MS) and methicillin-resistant (MR) strains. It also demonstrates activity against $S$ pneumoniae, including penicillin-susceptible, -intermediate and -resistant strains. Linezolid is active against vancomycin-susceptible and vancomycin-resistant strains of enterococci including vanA and vanB phenotypes. Because these antimicrobials are new, there are no National Committee for Clinical Laboratory Standard (NCCLS) breakpoints available. The Food and Drug Administration breakpoints for susceptible, intermediate and resistant strains are 2, 4 and $8 \mu \mathrm{g} / \mathrm{mL}$ (Enterococcus species), respectively (35).

Oxazolidinones have poor activity against Gram-negative aerobes as shown in Table $2(2,21,25,33,36,42)$. Not included in this table is the activity against Mycobacterium tuberculosis and Mycobacterium avium complex (MAC) because MIC data were not available (43). However, published studies report the activity against these two important pathogens $(21,42,44)$. Susceptible and drug-resistant strains of $M$ tuberculosis were inhibited by $0.5 \mu \mathrm{g} / \mathrm{mL}$ and $2.0 \mu \mathrm{g} / \mathrm{mL}$ of linezolid (21). Certain oxazolidinones have demonstrated activity against MAC (42). The activity is correlated with hydrophobicity of the drug molecule (42). Further research in this area is warranted.

Oxazolidinones have activity against anaerobes as shown in Table $3(2,21,25,27,33,35,36)$. Linezolid generally has mod- 
TABLE 5

Pharmacokinetic parameters of linezolid, vancomycin and quinupristin/dalfopristin following a single oral dose

\begin{tabular}{|c|c|c|c|c|c|c|c|c|c|c|}
\hline \multirow[b]{2}{*}{ Drug } & \multirow{2}{*}{$\begin{array}{c}\text { Dosage } \\
(\mathrm{mg})\end{array}$} & \multirow[b]{2}{*}{$\% F$} & \multirow{2}{*}{$\underset{(\mu \mathrm{g} / \mathrm{mL})}{\mathrm{C}_{\max }}$} & \multirow[b]{2}{*}{$\mathrm{T}_{\text {max }}(\mathrm{h})$} & \multirow{2}{*}{$\begin{array}{c}\mathrm{AUC}_{24} \\
(\mu \mathrm{g} \times \mathrm{h} / \mathrm{mL})\end{array}$} & \multirow[b]{2}{*}{$T_{1 / 2}(h)$} & \multirow{2}{*}{$\begin{array}{c}\text { Vd } \\
\text { L (L/kg) }\end{array}$} & \multirow{2}{*}{$\begin{array}{c}\% \text { Protein } \\
\text { binding }\end{array}$} & \multicolumn{2}{|c|}{ Dose adjustment* } \\
\hline & & & & & & & & & Renal & Hepatic \\
\hline \multirow[t]{3}{*}{ Linezolid } & 375 & 100 & 8.2 & 1.67 & 65.5 & 4.98 & $44.3(0.6)$ & 31 & No & No \\
\hline & 500 & 100 & 10.4 & 1.38 & 74.3 & 4.59 & $45.0(0.6)$ & 32 & No & No \\
\hline & 625 & 100 & 12.7 & 1.33 & 102.0 & 4.87 & $45.0(0.6)$ & NA & No & No \\
\hline \multirow[t]{2}{*}{ Vancomycin } & 500 & $<5$ & $10-25$ & 1.0 & $\mathrm{~N} / \mathrm{A}$ & 7.0 & $10.5(0.15)$ & $44-82$ & Yes & No \\
\hline & 1000 & $<5$ & $20-50$ & 1.0 & $\mathrm{~N} / \mathrm{A}$ & 7.0 & $10.5(0.15)$ & $44-82$ & Yes & No \\
\hline Quinupristin & $7.5 \mathrm{mg} / \mathrm{kg}$ & $<5$ & 2.7 & 0.92 & 3.2 & 0.91 & $70(1.0)$ & $55-78$ & No & t \\
\hline Dalfopristin & & $<5$ & 8.1 & 0.92 & 8.5 & 0.91 & $70(1.0)$ & $11-26$ & No & t \\
\hline
\end{tabular}

Linezolid: Single oral dose; Vancomycin and quinupristin/dalfopristin: Single intravenous dose. *Dose adjustment refers to whether the antimicrobial requires any dosage adjustments in patients with impaired renal or hepatic function (see text for details). Dosage only applies to peak concentration reached in the plasma/serum $\left(C_{\max }\right.$ and the area under the plasma concentration time curve (AUC) after a single dose. The other parameters represent an average of the values available in the literature irrespective of dosage. ${ }^{\dagger}$ Dosage adjustment may be necessary although precise recommendations have not been validated. F Bioavailability; N/A Information not available; $T_{1 / 2}$ Half Life; $T_{\max }$ Time to reach $C_{\max }$; Vd Volume of distribution. Adapted from References 37-40, 46-50

erate to good activity against these organisms, with less activity against Bacteroides fragilis and Clostridium difficile.

Very little data exist on atypical bacteria such as Chlamydia pneumoniae and Mycoplasma pneumoniae (Table 4) $(25,36,45)$. Further research is required to assess the activity against these key respiratory pathogens.

Recently, linezolid was tested in combination with various beta-lactams, tetracycline, aminoglycosides, teicoplanin, bacitracin, and metronidazole against susceptible and resistant strains of Staphylococcus species, $S$ pneumoniae, Enterococcus species and enteric bacteria. Checkerboard testing documented that $99.4 \%$ of all determinations showed additive or indifferent effects.

\section{PHARMACOKINETICS}

Relatively few pharmacokinetic studies are available for the oxazolidinones. Pharmacokinetic parameters, available primarily from conference abstracts, are summarized in Table 5 (46-50).

Absorption: Oxazolidinones are $100 \%$ bioavailable; therefore, the dosage does not need to be adjusted when switching from parenteral to oral dosage forms. These antimicrobial agents are rapidly absorbed and reach peak plasma concentrations approximately 1 to $2 \mathrm{~h}$ after oral administration (47). The pharmacokinetic parameters are only slightly affected by food consumption. The linezolid $\mathrm{C}_{\max }$ is lowered by approximately $23 \%$ when administered orally with a high-fat diet; however, the area under the plasma concentration-time curve (AUC) remains constant (51). Therefore, linezolid can be taken with or without food (51).

At steady state (after multiple dosing), linezolid's $\mathrm{C}_{\max }$ with a $625 \mathrm{mg}$ twice-daily dosage regimen is approximately $19 \mu \mathrm{g} / \mathrm{mL}$ and the minimum concentration in serum $\left(C_{\min }\right)$ is approximately $8 \mu \mathrm{g} / \mathrm{mL}$. Thus, with organisms possessing a linezolid $\mathrm{MIC}_{90}$ of $4 \mu \mathrm{g} / \mathrm{mL}$ or less, this agent would achieve plasma concentrations above the $\mathrm{MIC}_{90}$ for the entire dosage interval (47). Thus, the majority of adult clinical trials have investigated a $600 \mathrm{mg}$ twice-daily regimen.

Distribution: The volume of distribution of linezolid is approximately $0.6 \mathrm{~L} / \mathrm{kg}$, and protein binding is low at approx- imately $30 \%$ (52). Limited data are available on the tissue and fluid distribution of linezolid; however, relative to serum (tissue or fluid/serum) linezolid achieves the following penetrations in cerebral spinal fluid, saliva, bronchoalveolar lavage of $30 \%, 120 \%$ and $450 \%$, respectively (53).

Metabolism: Linezolid is metabolized by nonenzymatic oxidation and not by the major human cytochrome P-450 isozymes (54). There is also no inhibition or induction of these enzyme systems; therefore, linezolid is unlikely to contribute to drug interactions via this pathway (55). Once metabolized, the metabolites do not contribute to the antimicrobial activity because the morpholine ring undergoes oxidation and is rendered inactive (55).

Elimination: The elimination half-life of linezolid is approximately 4.5 to $5.5 \mathrm{~h}$. At steady state, approximately $30 \%$ of the linezolid dose is excreted unchanged in the urine $(48,55)$. Dosage adjustment in patients with creatinine clearances as low as 10 to $39 \mathrm{~mL} / \mathrm{min}$ should not be required (48). No data are available on dosage adjustment in patients with renal failure or on dialysis. Single dose investigations in patients with hepatic impairment reported that changes in the pharmacokinetic parameters were not statistically significant $(49,50)$. Dosage adjustment in patients with mild to moderate hepatic disease (Child-Pugh score grades A or B) is not necessary $(49,50)$.

A recent study of the effects of sex and age on the pharmacokinetics of linezolid suggest that these variables do not significantly change the pharmacokinetic profile (56). A dosage adjustment based on age or sex is not recommended (56).

\section{PHARMACODYNAMICS}

Pharmacodynamic parameters are defined as the relationship between drug concentration and the antimicrobial effect (57). To predict antimicrobial activity, peak serum concentration $\left(\mathrm{C}_{\max }\right)$ and the area under the serum concentration-time curve (AUC) relative to the MIC (AUC/MIC) or time above the MIC ( $>$ MIC) may be used $(57,58)$. Antimicrobial activity requires that the drug molecules bind to or interact with a specific target site in the pathogen (58). The bound drug must also occupy a certain number of binding sites and 
remain in the binding site long enough to exert its effect (58). By measuring the serum concentration of the drug, an estimation of the antimicrobial activity can be obtained $(57,58)$.

Antimicrobial activity is either concentration dependent or time dependent $(57,58)$. With concentration-dependent drugs (aminoglycosides, fluoroquinolones), the ability to kill bacteria is exerted by high concentrations of the antimicrobial at the infection site. The ratio of $\mathrm{C}_{\max }$ to the minimum concentration required to inhibit the bacteria $\left(\mathrm{C}_{\max } / \mathrm{MIC}\right)$ is a good predictor of bacterial eradication. A ratio of at least 10:1 allows concentration-dependent antimicrobials to achieve excellent bacterial killing and prevent the development of bacterial resistance (59-62). The above are also correlated with the AUC/MIC $(62,63)$. Time-dependent antimicrobials (penicillins, cephalosporins) require drug concentrations above the MIC ( $T>$ MIC) for extended periods of time to exert their effects $(57,58)$. These drugs reach peak killing rates at relatively low serum concentrations (eg, four times MIC) $(57,58)$. Therefore, exposure time, and not peak drug concentration, is important. The serum concentrations for time-dependent antimicrobials should be above the MIC for at least $40 \%$ of the dosing interval for effective bacterial eradication (64).

Linezolid is thought to be a time-dependent antimicrobial because, in the results of recent studies, there was no significant increase in activity with an increase in dose $(21,23,25,29,65)$. Recently, the pharmacodynamics of linezolid were characterized in patients with significant infections due to resistant Gram-positive organisms or intolerance to conventional therapy. The reported T $>$ MIC of $85 \%$ was associated with maximal bacterial eradication and clinical cure. Subinhibitory drug concentrations and postantimicrobial effects are also important factors when determining dosing schedules (59). It has been demonstrated in vitro that linezolid inhibits virulence factors at sub-MIC concentrations because of a significant decrease in alpha-haemolysin, gamma-haemolysin, coagulase, streptolysin $O$ and DNAase production by certain bacterial strains (66). This contributes to the pharmacodynamic effect of linezolid in the treatment of Gram-positive infections (66).

\section{CLINICAL TRIALS}

Clinical trials were identified by searching MEDLINE and The Cochrane Library, reviewing recent conference abstracts, contacting the pharmaceutical industry, and conducting bibliographic searches of identified journal articles. Clinical trials in adults, primarily focusing on the treatment of community-acquired pneumonia (CAP) and nosocomial pneumonia, and skin and soft tissue infections, have been included. Studies investigating multiple indications simultaneously, case reports, small case series, and studies including pooled or combined data from previously conducted trials were omitted. The majority of studies are unpublished, phase III clinical trials involving linezolid, and are summarized in Table 6 $(67,68)$. Data from most clinical trials were obtained from the pharmaceutical industry (unpublished data); however, several recently published abstracts report on combined results from these clinical trials or provide subgroup analysis based on geographical location (68-77). There were no clinical trials comparing linezolid with the new flouroquinolones. No prospective clinical trials were identified using eperezolid for pneumonia or skin and soft tissue infections.

CAP: Linezolid has been investigated in the treatment of adult CAP in two large, phase III clinical trials totalling over 1000 patients (Table 6). Linezolid achieved clinical cure rates of over $90 \%$ in both trials using the Investigator's Assessment of Clinical Outcome criteria. The most commonly reported pathogens in these trials were $S$ pneumoniae, $H$ influenzae and $S$ aureus. Compared with oral cefpodoxime proxetil or parenteral ceftriaxone/oral cefpodoxime, there were no significant differences in clinical cure rates overall. It should be mentioned that a cephalosporin alone without suitable atypical coverage with a macrolide is not the usual treatment in North America. However, in patients with concurrent $S$ pneumoniae bacteremia, linezolid was reported to be more effective. Both the microbiological eradication and clinical cures rates were $93.3 \%$ and $69.6 \%$ for linezolid and the comparators, respectively. This result was surprising because the study was not powered to show a difference. Clearly, these results need to be duplicated.

Linezolid was found to be well tolerated. The most common adverse effects reported were diarrhea (11\%), nausea (6.3\%) and headache $(7.3 \%)$. Comparatively, the rates of adverse events were marginally higher in patients who were receiving linezolid; however, the overall frequencies were low and rarely caused patients to withdraw from the studies (68-77).

There is also initial evidence from subgroup analysis of these trials that linezolid may be an effective agent for the treatment of CAP caused by penicillin-resistant $S$ pneumoniae (69).

Nosocomial pneumonia: A double-blind, randomized, comparative study was performed in patients with nosocomial pneumonia treated with linezolid/aztreonam or vancomycin/aztreonam (Table 6). Continued treatment with aztreonam was optional if Gram-negative pathogens were not identified. The most common pathogens were $S$ aureus (including MRSA) and $S$ pneumoniae. Clinical, microbiological and overall outcomes were reported to be similar between both groups. Microbiological eradication of methicillin-resistant $S$ aureus (MRSA) occurred in 65.2 (15 of 23) linezolid-treated and $77.8 \%$ (seven of nine) of vancomycin-treated patients (73). A greater percentage of deaths (49 of 193, 25.4\%) occurred in patients treated with vancomycin versus linezolid (36 of 203, $17.7 \%$ ); however, the cause was determined to be unrelated to the study medication (73).

Skin and soft tissue infections: Linezolid has been compared with clarithromycin in two large, phase III clinical trials investigating uncomplicated skin and soft tissue infections in over 1000 patients (Table 6). These infections commonly included simple abscesses, impetiginous lesions, furuncles, carbuncles, cellulitis and erysipelas. It should be noted that cloxacillin or a first-generation cephalosporin is a more appropriate comparator in Canada than clarithromycin. 
TABLE 6

Results of clinical trials involving linezolid in adults

\begin{tabular}{|c|c|c|c|c|c|c|c|}
\hline \multirow[b]{2}{*}{ Reference (date) } & \multirow[b]{2}{*}{ Design } & \multirow[b]{2}{*}{$\mathbf{n}()$} & \multirow[b]{2}{*}{ Indication } & \multirow[b]{2}{*}{ Regimen } & \multicolumn{3}{|c|}{ Results } \\
\hline & & & & & $\begin{array}{l}\text { Duration } \\
\text { (days) }\end{array}$ & $\begin{array}{l}\text { Clinical } \\
\text { cure }\end{array}$ & $\begin{array}{l}\text { Microbiological } \\
\text { cure* }^{*}\end{array}$ \\
\hline $\begin{array}{l}\text { Pharmacia \& Upjohn, } \\
\text { study } 51 \\
\text { (August 1999) }\end{array}$ & $\begin{array}{l}\text { Prospective, } \\
\text { single-blind, } \\
\text { comparative }\end{array}$ & $\begin{array}{c}548 \\
(417)\end{array}$ & $\begin{array}{l}\text { CAP } \\
\text { (outpatient) }\end{array}$ & $\begin{array}{l}\text { Linezolid } 600 \mathrm{mg} \\
\text { q } 12 \mathrm{~h} \text { versus } \\
\text { cefpodoxime proxetil } \\
200 \mathrm{mg} \mathrm{q} 12 \mathrm{~h}\end{array}$ & $10-14$ & $\begin{array}{l}\text { Linezolid } \\
\text { 199/205 }(97.1 \%)^{\dagger} \\
\text { cefpodoxime } \\
204 / 212(96.2 \%)^{\dagger}\end{array}$ & $\begin{array}{l}\text { Linezolid } 87.8 \% \\
\text { Cefpodoxime } 89.4 \%\end{array}$ \\
\hline $\begin{array}{l}\text { Pharmacia \& Upjohn } \\
\text { study } 33 \\
\text { September } 1999 \\
\text { Cammarata et al (68) }\end{array}$ & $\begin{array}{l}\text { Prospective, } \\
\text { randomized, } \\
\text { open-label } \\
\text { (initially } \\
\text { evaluator blind), } \\
\text { comparative }\end{array}$ & $\begin{array}{c}747 \\
(534)\end{array}$ & $\begin{array}{l}\text { CAP } \\
\text { (with } \\
\text { hospital } \\
\text { admission) }\end{array}$ & $\begin{array}{l}\text { Linezolid IV } 600 \mathrm{mg} \\
\mathrm{q} 12 \mathrm{~h} \text { followed by } \\
\text { oral } 600 \mathrm{mg} \mathrm{q} 12 \mathrm{~h} \\
\text { versus } \\
\text { ceftriaxone IV } 1 \mathrm{~g} \\
\mathrm{q} 12 \mathrm{~h} \text { followed by } \\
\text { oralcefpodoxime } 200 \mathrm{mg} \\
\mathrm{q} 12 \mathrm{~h} \text {; (aztreonam IV } \\
1-2 \mathrm{~g} \mathrm{q} 8 \mathrm{~h} \text { could be } \\
\text { used in linezolid group } \\
\text { for Gram-negative } \\
\text { coverage) }\end{array}$ & $\begin{array}{l} \\
\text { g } \\
\\
\\
\end{array}$ & $\begin{array}{l}\text { Linezolid } \\
247 / 272(90.8 \%)^{\ddagger} \\
\text { Ceftriaxone/ } \\
\text { cefpodoxime } \\
225 / 254(88.6 \%) \\
\text { (8 patients' data } \\
\text { missing or } \\
\text { indeterminate) }\end{array}$ & $\begin{array}{l}\text { Linezolid: } 89.9 \% \\
\text { Ceftriaxone/ } \\
\text { cefpodoxime } 87.1 \%\end{array}$ \\
\hline $\begin{array}{l}\text { Pharmacia \& Upjohn, } \\
\text { study 48a } \\
\text { (September 1999) } \\
\text { Rubinstein et al (74) }\end{array}$ & $\begin{array}{l}\text { Prospective, } \\
\text { randomized, } \\
\text { double-blind }\end{array}$ & $\begin{array}{c}396 \\
(204)\end{array}$ & $\begin{array}{l}\text { Nosocomial } \\
\text { pneumonia }\end{array}$ & $\begin{array}{l}\text { Linezolid IV } 600 \mathrm{mg} \\
\mathrm{q} 12 \mathrm{~h} \text { versus } \\
\text { vancomycin IV } \\
1 \mathrm{~g} \mathrm{q} 12 \mathrm{~h} \\
\text { (aztreonam IV } 1 \text { to } 2 \mathrm{~g} \\
\mathrm{q} 8 \mathrm{~h} \text { used for Gram } \\
\text { negative coverage) }\end{array}$ & $7-21$ & $\begin{array}{l}\text { Linezolid } \\
71 / 107(66.4 \%)^{\ddagger} \\
\text { and vancomycin } \\
62 / 91(68.1 \%)\end{array}$ & $\begin{array}{l}\text { Linezolid 36/53 } \\
(67.9 \%) \text { and } \\
\text { vancomycin } \\
28 / 39(71.8 \%)\end{array}$ \\
\hline $\begin{array}{l}\text { Pharmacia \& Upjohn, } \\
\text { study } 39 \\
\text { (August 1999) }\end{array}$ & $\begin{array}{l}\text { Prospective, } \\
\text { randomized, } \\
\text { double-blind, } \\
\text { comparative }\end{array}$ & $\begin{array}{c}332 \\
(251)\end{array}$ & $\begin{array}{l}\text { Various, } \\
\text { uncomplicated } \\
\text { skin and soft } \\
\text { tissue infection }\end{array}$ & $\begin{array}{l}\text { Linezolid } 400 \mathrm{mg} \text { bid } \\
\text { versus } \\
\text { clarithromycin } 250 \mathrm{mg} \\
\text { bid }\end{array}$ & $7-14$ & $\begin{array}{l}\text { Linezolid } \\
\text { 118/127 (92.9\%) } \\
\text { Clarithromycin } \\
115 / 124(92.7 \%)^{\dagger}\end{array}$ & $\begin{array}{l}\text { Linezolid 98.1\% } \\
\text { Clarithromycin } \\
97.1 \%\end{array}$ \\
\hline $\begin{array}{l}\text { Pharmacia \& Upjohn, } \\
\text { study 39a } \\
\text { (August 1999) }\end{array}$ & $\begin{array}{l}\text { Prospective, } \\
\text { randomized, } \\
\text { double-blind, } \\
\text { comparative }\end{array}$ & $\begin{array}{l}753 \\
(623)\end{array}$ & $\begin{array}{l}\text { Various, tissue } \\
\text { uncomplicated } \\
\text { skin and soft } \\
\text { infection }\end{array}$ & $\begin{array}{l}\text { Linezolid } 400 \mathrm{mg} \text { bid } \\
\text { versus } \\
\text { clarithromycin } \\
250 \mathrm{mg} \text { bid }\end{array}$ & $7-14$ & $\begin{array}{l}\text { Linezolid } \\
\text { 299/314 (95.2\%) } \\
\text { clarithromycin }^{\dagger} \\
287 / 309(92.9 \%)^{\dagger}\end{array}$ & $\begin{array}{l}\text { Linezolid 90.9\% } \\
\text { Clarithromycin } \\
84.1 \%\end{array}$ \\
\hline Stevens et al (76) & $\begin{array}{l}\text { Prospective, } \\
\text { randomized, } \\
\text { double-blind, } \\
\text { double-dummy }\end{array}$ & $\begin{array}{c}826 \\
(600)\end{array}$ & $\begin{array}{l}\text { Various, } \\
\text { complicated } \\
\text { skin or deeper } \\
\text { soft tissue } \\
\text { infection, } \\
\text { may have } \\
\text { required surgical } \\
\text { intervention }\end{array}$ & $\begin{array}{l}\text { Linezolid IV or } \\
\text { oral } 600 \text { mg q } 12 \mathrm{~h} \\
\text { versus } \\
\text { oxacillin IV } 2 \mathrm{~g} \mathrm{q} 6 \mathrm{~h} \\
\text { or oral dicloxacillin } \\
500 \mathrm{mg} \mathrm{q} 6 \mathrm{~h}\end{array}$ & $10-21$ & $\begin{array}{l}\text { Linezolid } \\
264 / 298(88.6 \%)^{\dagger} \\
\text { oxacillin/ } \\
\text { dicloxacillin } \\
259 / 302(85.8 \%)^{\dagger}\end{array}$ & $\begin{array}{l}\text { Linezolid } 88.1 \% \\
\text { Oxacillin/cloxacillin } \\
86.1 \%\end{array}$ \\
\hline
\end{tabular}

Clinical Cure Not defined (eg, in terms of total resolution of symptoms or improvement in chest radiograph, etc.); ${ }^{*}$ Microbiological success rates (based on microbiologically evaluable population; ${ }^{\dagger}$ Investigator's Assessment of Clinical Outcomes; ${ }^{\ddagger}$ Included Investigator's Assessment of Clinical Outcome,

Sponsor's Assessment of Clinical Outcomes and Patient Overall Outcome. O Clinically evaluable patients; CAP Community-acquired pneumonia; Duration Length of treatment; IV Intravenous; n Number of patients randomized; NA Information not available. Adapted from references 53,67

In both studies, linezolid achieved cure rates of over $90 \%$ using the Investigator's Assessment of Clinical Outcome criteria, and were comparable with clarithromycin (Table 6). In the second of the two studies, the microbiological cure rates for evaluable patients were $90.9 \%$ for linezolid and $84.1 \%$ for clarithromycin. Linezolid was as effective as clarithromycin in eradicating $S$ aureus, $S$ epidermidis and Staphylococcus pyogenes.

Linezolid has been compared with oxacillin/dicloxicillin for the treatment of complicated skin and soft tissue infections (67). These infections commonly included major abscesses, infected ulcers, major burns, or deep and extensive cellulitis, etc. The study had a double-blind, randomized, placebo controlled design in which patients were given either linezolid $600 \mathrm{mg}$ intravenously every $12 \mathrm{~h}$ and switched to $600 \mathrm{mg}$ orally every $12 \mathrm{~h}$ or intravenous oxacillin $2 \mathrm{~g}$ every $6 \mathrm{~h}$ and switched to oral dicloxacillin $500 \mathrm{mg}$ every $6 \mathrm{~h}$. Linezolid achieved similar clinical cure rates as oxacillin/dicloxacillin (Table 6). Linezolid was as effective as oxacillin/dicloxacillin in eradicating $S$ aureus, Staphylcoccus agalactiae and $S$ pyogenes (53).

Selected clinical trials involving resistant organisms Methicillin-resistant Staphylococcus species infections: An open-label, randomized, comparative study was conducted in patients with methicillin-resistant Staphylococcus species (MRSS) infections who were being treated with either linezolid $600 \mathrm{mg}$ intravenous every $12 \mathrm{~h}$ for the entire treatment duration (or switched to oral $600 \mathrm{mg}$ every $12 \mathrm{~h}$ ), or vancomycin $1 \mathrm{~g}$ intravenous every $12 \mathrm{~h}$ for the entire treatment duration. Infections such as MRSA and methicillinresistant Staphylococcus epidermidis (MRSE) including 
pneumonia, skin and soft tissue, urinary tract, 'other' infections and bacteremia of unknown source were investigated. Overall, 254 patients were clinically evaluable. Linezolid achieved an overall cure rate (based on the Investigator's Assessment of Clinical Outcome) of $94.2 \%$ compared with $87.3 \%$ in the vancomycin-treatment group. It was concluded that linezolid and vancomycin were equally effective in treating MRSS infections (eg, MRSA, MRSE) (53). In nosocomial pneumonia caused by MRSA, eradication rates were $65.2 \%$ (15 of 23 ) and $77.8 \%$ (seven of nine) for linezolid and vancomycin, respectively (74). A recent, randomized multicentre trial compared the length of hospital stay (LOS) of 406 patients with known or suspected MRSS infections treated with linezolid or vancomycin (78). Linezolid-treated patients had a LOS that was five and eight days shorter $(\mathrm{P}=0.05$ and $\mathrm{P}=0.003)$ in the complicated skin and soft tissue infection intent-to-treat and clinically evaluable patients, respectively. As well, linezolid treated patients had more discharges in the first week of treatment $(\mathrm{P}=0.001)$, as well as fewer days of intravenous therapy $(\mathrm{P}=0.0001)$ than the vancomycin-treated patients. Clinical studies need to be performed that assess the ability to step down from intravenous vancomycin to oral linezolid in patients with complicated skin and soft tissue infections.

Vancomycin-resistant enterococcus: A multicentre study performed in Canada and United States compared two linezolid dosage regimens for treatment of vancomycin-resistant enterococcus (VRE) infections (53). It should be mentioned that, because no treatment was officially indicated for VRE, the United States Food and Drug Administration required comparison with two different doses of linezolid. The study had a randomized, double-blind design. One group of patients received $600 \mathrm{mg}$ of linezolid intravenous or oral every $12 \mathrm{~h}$ and the other group of patients received $200 \mathrm{mg}$ intravenously or orally every $12 \mathrm{~h}$ for seven to 28 days. A total of 145 patients were enrolled in the study. Inclusion criteria allowed for the enrollment of patients with various types of infections including pneumonia, skin and soft tissue infections, and urinary tract infections. Results indicated that the $600 \mathrm{mg}$ regimen produced higher cure rates on intent-to-treat analysis, although a statistically significant difference from the $200 \mathrm{mg}$ regimen was not observed. This may have been because of a small sample size. Cure rates varied in the $600 \mathrm{mg}$ regimen from $50 \%$ for "bacteremia of unknown origin" to $85 \%$ for "other". Corresponding cure rates in the $200 \mathrm{mg}$ regimen ranged from $29 \%$ for "bacteremia of unknown origin" to $100 \%$ for skin and soft tissue infections (five of five). Overall, it appears that linezolid is a promising agent for the treatment of VRE.

\section{ADVERSE EFFECTS}

Initial phase I studies assessing the safety of intravenous and oral linezolid in double-blind, placebo controlled trials over 7.5 and 14.5 days, respectively, found gastrointestinal adverse effects were common in the linezolid arm $(46,47)$. Discoloration of the tongue was also noted, although there were no associate alterations in taste $(46,47)$. Commonly
TABLE 7 Frequency of occurrence of adverse effects with linezolid,
vancomycin and quinupristin/dalfopristin $(\mathrm{Q} / \mathrm{D})$ in
controlled, clinical trials

\begin{tabular}{lccc}
\hline Adverse effect & $\begin{array}{c}\text { Linezolid } \\
(\mathbf{n}=\mathbf{2 0 4 6})\end{array}$ & Vancomycin & Q/D \\
\hline Diarrhea & +++ & + & + \\
Headache & +++ & + & + \\
Nausea & +++ & + & ++ \\
Vomiting & ++ & + & + \\
Insomnia & ++ & + & + \\
Constipation & ++ & + & + \\
Rash or allergic & ++ & ++ & + \\
Dizziness & ++ & + & + \\
Fever & + & + & + \\
Taste alteration & + & - & + \\
Vaginal moniliasis & + & + & + \\
Abnormal liver function tests & + & - & ++ \\
Tongue discoloration & + & - & - \\
Arthralgia & - & - & +++ \\
Myalgia & - & - & +++ \\
Venous events & + & + & +++ \\
Nephrotoxicity & - & + & - \\
Ototoxicity & - & + & - \\
\hline Comparators & + & +
\end{tabular}

Comparators included: clarithromycin, cefpodoxime, ceftriaxone, dicloxacillin, oxacillin and vancomycin. + Less than $2 \% ;++2 \%$ to $5 \%$; $+++5 \%$ to $6.5 \%$. Adapted from references $38-40,50,82$

reported adverse effects in the 517 patients in open label, phase II intravenous and oral trials include nausea (5.4\%), diarrhea (5.2\%), tongue discoloration $(2.5 \%)$ and oral monilia $(2.3 \%)$ (Table 7) (79). A dose-response relationship with adverse effects was not observed. Injection or catheter pain was noted in $1.4 \%$ of patients.

In an open label, noncomparative, compassionate use trial of linezolid in 386 patients with 'significant' infections caused by clinically resistant pathogens or patients intolerant of conventional regimens, the overall adverse effect rate was $32.9 \%(80)$. Adverse effects were considered serious in $5.7 \%$ of patients and required discontinuation in $9.3 \%(80)$.

Bruss and colleagues (81) conducted a comparison of oral and intravenous linezolid (600 mg twice daily) in two openlabel and three double-blind comparator controlled phase III trials. Comparator arms included clarithromycin, vancomycin, ceftriaxone/cefpodoxime, oxacillin/dicloxacillin or cefpodixime, respectively. Adverse effects were reported in $58.6 \%$ linezolid patients $(n=1498)$ and $52.4 \%$ of comparatortreated patients $(n=1464)(75)$. The most common reported adverse effects in linezolid patients compared with comparator-treated patients were diarrhea ( $8.3 \%$ versus $6.4 \%$ ), nausea (6.6\% versus $4.6 \%$ ), headache (5.7\% versus $4.4 \%)$ and vomiting (4.3\% linezolid) (81). The most common drug-related adverse effects with linezolid and comparators were diarrhea ( $4 \%$ versus $2.7 \%$ ), headache $(1.9 \%$ versus $1 \%$ ) and nausea (3.3\% versus $1.8 \%)(81)$. Discontinuation of linezolid and comparators as a result of drug-related adverse effects occured in $2.1 \%$ and $1.7 \%$ of patients respectively. Serious adverse effects were reported in $14.8 \%$ and $13.9 \%$ of patients in the linezolid and comparator arms, respectively. 
Linezolid-related thrombocytopenia (ie, less than $75 \%$ of lower limit of normal or baseline) has also been observed in $2.4 \%$ (range $0.3 \%$ to $10 \%$ ) of linezolid-treated patients compared with $1.5 \%(0.3 \%$ to $7.0 \%)$ in the comparator arms (82). Linezolid-induced thrombocytopenia usually occurs after two weeks of treatment (although it can occur after only a few days of therapy) and is reversible upon discontinuation of treatment. Risk factors for linezolid-induced thrombocytopenia include treatment longer than two weeks, pre-existing myelosuppression, concurrent drugs that produce myelosuppression and patients with a chronic infection who have received previous or concomitant antibiotic therapy. The above patients should have complete blood counts monitored weekly, and discontinuation of linezolid should be considered in patients who developed worsening myelosuppression (82). In addition to the adverse effects described above, vaginal moniliasis, hypertension, dyspepsia, localized abdominal pain and pruritus have been reported. A list of linezolid-related adverse events (compared with vancomycin and quinupristin/dalfopristin) occuring in $1 \%$ or more of patients from the product monograph may be found in Table 7 .

\section{DRUG INTERACTIONS}

Over the past few decades, several oxazolidinone compounds have been studied with respect to monoamine oxidase (MAO) inhibitory activity and potential antidepressant properties. Martin and colleagues (83) assessed the activity of linezolid using an in vitro microtitre plate assay on human monoamine oxidase (MAO A). Results indicated that linezolid is a weak, competitive (reversible) inhibitor of human MAO A in contrast to classic MAO inhibitors or other oxazolidinone compounds that nonselectively and irreversibly inhibit MAO A (83). To date, phase II and phase III trials have not identified any reports of MAO inhibition among linezolid recipients. As a precaution, the manufacturer has indicated that prescribers should be aware that response to adrenergic agents (eg, dopamine, epinephrine) may be enhanced during linezolid therapy and that dose adjustment may be required. A study of normotensive subjects receiving linezolid and phenylpropanolamine hydrochloride or pseudoephedrine hydrochloride found a reversible increase in blood pressure following a couple of doses of the concomittant agent with linezolid (83). Mean maximum blood pressure above baseline ranged from an increase of 26 to $32 \mathrm{mmHg}$ (83). Interactions between linezolid and serotonergic agents (eg, dextromethorphan) have not been observed in healthy subjects or during clinical trials (83). Nevertheless, the manufacturer recommends that clinicians be aware of the signs and symptoms of serotonin syndrome (eg, hyperpyrexia, cognitive dysfunction) in patients receiving concomitant agents (83).

Because linezolid is oxidized, there appears to be no interaction between linezolid on human cytochrome P450 systems. Hence, interactions between linezolid and drugs metabolized through major cytochrome $\mathrm{P} 450$ isoforms are not expected (83).

\section{ROLE IN THERAPY}

Linezolid is a novel semisynthetic oxazolidinone with a novel mechanism of action, and is available in both oral and parenteral formulations in the United States (update Canadian information). Pharmacokinetic data indicate linezolid is virtually $100 \%$ bioavailable, and dose adjustment between intravenous and oral dosing is not necessary. In addition, the drug interaction profile appears to be minimal, although caution has been expressed with concomitant use of an adrenergic/serotonergic agent.

Linezolid has been studied and found to be efficacious in complicated and uncomplicated skin and soft tissue infections, nosocomial pneumonia, and CAP caused by methicillin-susceptible and -resistant $S$ epidermidis and $S$ aureus, $S$ pyogenes and $S$ pneumoniae. Based on available data, linezolid appears to be a safe and tolerable agent available both orally and intravenously for the treatment of Gram-positive infections in patients with pathogens resistant to conventional agents or in patients intolerant (eg, allergic) of conventional agents. The authors believe that linezolid will become the treatment of choice for VRE infections because it is safer and cheaper than quinupristin/dalfopristin and can be used orally. For the treatment of CAP, linezolid will have a limited role because excellent and cheaper alternatives exist. However, for the treatment of hospital-acquired pneumonia in centres with a high prevalence of MRSA, linezolid will potentially have an important role. As well, in the treatment of complicated skin and soft tissue infections caused by MRSA, linezolid will have a role as an alternative to vancomycin. Linezolid's activity against resistant Gram-positive pathogens (MRSA, MRSE, VRE and penicillin-resistant $S$ pneumoniae), excellent oral bioavailability and twice daily administration will allow it to become a useful oral alternative to ambulatory intravenous therapy in patients who would normally receive long term intravenous therapy. A recent study by Willke and colleagues (84) suggests that oral linezolid may facilitate early discharge compared with conventional therapy in patients with MRSA. Further research regarding the use of linezolid in this capacity is required.

Concerns about antibiotic resistance and antibiotic selection pressures will limit the use of linezolid when other therapeutic options are available. In fact, a report of VRE infections resistant to linezolid has been published (85). Five patients with VRE infections, four of whom were transplant recipients, received long courses (21 to 40 days) of linezolid. These patients, who had VRE-infected abscesses or empyema, developed linezolid-resistant VRE, with a MIC ranging from 3 to $64 \mu \mathrm{g} / \mathrm{mL}$. No mechanism of resistance studies were performed; however, genotypic analysis confirmed that the isolates were genetically unrelated.

\section{CONCLUSIONS}

The oxazolidinones present a new option for the management of infections caused by Gram-positive organisms particularly MRSA, MRSE, VRE and penicillin-resistant $S$ pneumoniae. A favourable adverse effect profile has been reported in 
healthy volunteers and during clinical trials. Excellent oral bioavailability makes linezolid a favourable option for resistant Gram-positive infections only available for treatment by parenteral antimicrobials. This new class of antimicrobials will likely have an important role to play in the future.

\section{REFERENCES}

1. Fugitt RB, Luckenbaugh RW. 5-halomethyl-3-phenyl-2-oxazolidinones. US patent 4,128,654. December 5, 1978 .

2. Slee AM, Wuonola MA, McRipley RJ, et al. Oxazolidinones, a new class of synthetic antibacterial agents: in vitro and in vivo activities of DuP 105 and DuP 721. Antimicrob Agents Chemother 1987;31:1791-7.

3. Toxicity of Dup-105. Scrip World Pharmaceut News 1987;25:1-5.

4. Piper RC, Platte TF, Palmer JR. Data on File. Pharmacia and Upjohn Company, Kalamazoo, Michigan.

5. Pharmcast-International. 1995:7-1-484,487.

6. Brickner SJ, Hutchinson DK, Barbachyn MR, et al. Synthesis and antibacterial activity of U-100592 and U-100766, two oxazolidinone antibacterial agents for the potential treatment of multidrug-resistant Gram-positive bacterial infections. J Med Chem 1996;39:673-9.

7. Daly JS, Eliopoulos GM, Reiszner E, Moellering RC Jr. Activity and mechanism of action of DuP 105 and DuP 721, new oxazolidinone compounds. J Antimicrob Chemother 1988;21:721-30.

8. Gregory WA, Brittelli DR, Wang CL, et al. Antibacterials. Synthesis and structure-activity studies of 3-aryl-2- oxooxazolidines. 1. The "B" group. J Med Chem 1989;32:1673-81.

9. Park CH, Brittelli DR, Wang CL, et al. Antibacterials. Synthesis and structure-activity studies of 3-aryl-2- oxooxazolidines. 4. Multiplysubstituted aryl derivatives. J Med Chem 1992;35:1156-65.

10. Barbachyn MR, Brickner SJ, Gadwood RC, et al. Design, synthesis, and evaluation of novel oxazolidinone antibacterial agents active against multidrug-resistant bacteria. Adv Exp Med Biol 1998;456:219-38.

11. Tucker JA, Allwine DA, Grega KC, et al. Piperazinyl oxazolidinone antibacterial agents containing a pyridine, diazene, or triazene heteroaromatic ring. J Med Chem 1998;41:3727-35.

12. Genin M. Nitrogen-carbon-linked (Azolylphenyl)oxazolidinones with potent antibacterial activity against the fastidious Gram-Negative organisms Haemophilus influenzae and Moraxella catarrhalis. J Med Chem 1998;41:5144-7.

13. Genin MJ, Allwine DA, Anderson DJ, et al. Substituent effects on the antibacterial activity of nitrogen-carbon-linked (azolylphenyl) oxazolidinones with expanded activity against the fastidious Gram-negative organisms Haemophilus influenzae and Moraxella catarrhalis. J Med Chem 2000;43:953-70.

14. Shinabarger DL, Marotti KR, Murray RW, et al. Mechanism of action of oxazolidinones: effects of linezolid and eperezolid on translation reactions. Antimicrob Agents Chemother 1997;41:2132-6.

15. Lin AH, Murray RW, Vidmar TJ, Marotti KR. The oxazolidinone eperezolid binds to the 50S ribosomal subunit and competes with binding of chloramphenicol and lincomycin. Antimicrob Agents Chemother 1997;41:2127-31.

16. Prescott LM, Harley JP, Klein DA. In: Seivers EM, ed. Microbiology. Philadephia: Wm C Brown Publishers, 1996:228-9.

17. Matassova NB, Rodnina MV, Endermann R, et al. Ribosomal RNA is the target for oxazolidinones, a novel class of translational inhibitors. RNA 1999;5:939-46.

18. Cundliffe E, McQuillen J. Bacterial protein synthesis: the effects of antibiotics. J Mol Biol 1967;30:137-46.

19. Swaney SM, Aoki H, Ganoza MC, Shinabarger DL. The oxazolidinone linezolid inhibits initiation of protein synthesis in bacteria Antimicrob Agents Chemother 1998;42:3251-5.

20. Murray RW, Schaadt RD, Zurenko GE, Marotti KR. Ribosomes from an oxazolidinone-resistant mutant confer resistance to eperezolid in a Staphylococcus aureus cell-free transcription-translation assay. Antimicrob Agents Chemother 1998;42:947-50.

21. Zurenko GE, Yagi BH, Schaadt RD, et al. In vitro activities of U-100592 and U-100766, novel oxazolidinone antibacterial agents. Antimicrob Agents Chemother 1996;40:839-45.

22. Zurenko GE, Todd WM, Hafkin B, et al. Development of linezolid resistant Enterococcus faecium in two compassionate use program patients treated with linezolid. 39th Interscience Conference on Antimicrobial Agents and Chemotherapy. San Francisco, September 26 to 29, 1999.

23. Kaatz GW, Seo SM. In vitro activities of oxazolidinone compounds U100592 and U100766 against Staphylococcus aureus and
Staphylococcus epidermidis. Antimicrob Agents Chemother 1996; 40:799-801.

24. Kloss P, Xiong L, Shinabarger DL, Mankin AS. Resistance mutations in $23 \mathrm{~S}$ rRNA identify the site of action of the protein synthesis inhibitor linezolid in the ribosomal peptidyl transferase center. J Mol Biol 1999;294:93-101.

25. Jones RN, Johnson DM, Erwin ME. In vitro antimicrobial activities and spectra of U-100592 and U-100766, two novel fluorinated oxazolidinones. Antimicrob Agents Chemother 1996;40:720-6.

26. Barry AL. In vitro evaluation of DuP 105 and DuP 721, two new oxazolidinone antimicrobial agents. Antimicrob Agents Chemother 1988;32:150-2.

27. Brumfitt W, Hamilton-Miller JMT. In-vitro microbiological activities of DuP105 and DuP721, novel synthetic oxazolidinones.

J Antimicrob Chemother 1988;21:711-20.

28. Eliopoulos GM, Wennersten CB, Gold HS, Moellering RC Jr. In vitro activities in new oxazolidinone antimicrobial agents against enterococci. Antimicrob Agents Chemother 1996;40:1745-7.

29. Jorgensen JH, McElmeel ML, Trippy CW. In vitro activities of the oxazolidinone antibiotics U-100592 and U-100766 against Staphylococcus aureus and coagulase-negative Staphylococcus species. Antimicrob Agents Chemother 1997;41:465-7.

30. Manzor O, Pawlak J, Saravolatz L. In-vitro activity of 29 antimicrobial agents against penicillin-resistant and -intermediate isolates of Streptococcus pneumoniae. J Antimicrob Chemother 1999; $43: 31-6$

31. Maple PAC, Hamilton-Miller JMT, Brumfitt W. Comparative in-vitro activities of vancomycin, teicoplanin, ramoplanin (formerly A16686), paldimycin, DuP721 and DuP105 against methicillin and gentamicin resistant Staphylococcus aureus. J Antimicrob Chemother 1989;23:517-25.

32. Mini E, Novelli A, Mazzei T, Periti P. Comparative in vitro activity of the new oxazolidinones DuP721 and DuP105 against staphylococci and streptococci. Eur J Clin Microbiol Infect Dis 1989;8:256-60.

33. Neu HC, Novelli A, Saha G, Chin NX. In vitro activities of two oxazolidinone antimicrobial agents, DuP 721 and DuP 105. Antimicrob Agents Chemother 1988;32:580-3.

34. Noskin GA, Siddiqui F, Stosor V, Hacek D, Peterson LR. In vitro activities of linezolid against important Gram-positive bacterial pathogens including vancomycin-resistant enterococci. Antimicrob Agents Chemother 1999;43:2059-62.

35. Wise R, Andrews JM, Boswell FJ, Ashby JP. The in-vitro activity of linezolid (U-100766) and tentative breakpoints. J Antimicrob Chemother 1998;42:721-8.

36. Goldstein EJ, Citron DM, Merriam CV. Linezolid activity compared to those of selected macrolides and other agents against aerobic and anaerobic pathogens isolated from soft tissue bite infections in humans. Antimicrob Agents Chemother 1999;43:1469-74.

37. Mason EO Jr, Lamberth LB, Kaplan SL. In vitro activities of oxazolidinones U-100592 and U-100766 against penicillinresistant and cephalosporin-resistant strains of Streptococcus pneumoniae. Antimicrob Agents Chemother 1996;40:1039-40.

38. Cunha BA. Vancomycin. Med Clin North Am 1995;79:817-31.

39. Lamb HM, Figgitt DP, Faulds D. Quinupristin/dalfopristin: A review of its use in the management of serious Gram-positive infections. Drugs 1999;58:1061-97.

40. Lundstrom TS, Sobel JD. Antibiotics for Gram-positive bacterial infections: Vancomycin, teicoplanin, quinupristin/dalfopristin and linezolid. Infect Dis Clin North Am 2000;14:463-474.

41. Jones RN, Ballow $\mathrm{CH}$, Biedenbach DJ. Antimicrobial activity of quinupristin/dalfopristin (RP 59500 Synercid) tested over 28,000 recent clinical isolates from 200 medical centres in the United States and Canada. Diagn Microbiol Infect Dis 1998;30:437-45.

42. Peters J, Kondo K, Lee R, Lin C, Inderlied C. In-vitro activity of oxazolidinones against Mycobacterium avium complex. J Antimicrob Chemother 1995;35:675-9.

43. Anderson DM. Dorland's Illustrated Medical Dictionary. Toronto: WB Saunders Company, 1994:173-4.

44. Cynamon MH, Klemens SP, Sharpe CA, Chase S. Activities of several novel oxazolidinones against Mycobacterium tuberculosis in a murine model. Antimicrob Agents Chemother 1999;43:1189-91.

45. Schulin T, Wennersten CB, Ferraro MJ, Moellering RC Jr, Eliopoulos GM. Susceptibilities of Legionella spp. to newer antimicrobials in vitro. Antimicrob Agents Chemother 1998;42:1520-3.

46. Stalker DJ, Wajszczuk CP, Batts DH. Linezolid safety, tolerance and pharmacokinetics following intravenous dosing twice daily for 7.5 days. International Conference on Macrolildes, Azalides, and Streptogramins 5. Seville, January 26 to 28, 2000.

47. Stalker DJ, Wajszczuk CP, Batts DH. Linezolid safety, tolerance and pharmacokinetics following oral dosing twice daily for 14.5 days. International Conference on Macrolildes, Azalides, and 
Streptogramins 5. Seville, January 26 to $28,2000$.

48. Brier ME, Stalker DJ, Aronoff GR, et al. Pharmacokinetics of linezolid in subjects witjh varying degrees of renal function and on dialysis. International Conference on Macrolildes, Azalides, and Streptogramins 5. Seville, January 26 to 28, 2000.

49. Hendershot PE, Jungbluth GL, Cammarata SK, Hopkin NK. Pharmacokinetics of linezolid in patients with liver disease. International Conference on Macrolildes, Azalides, and Streptogramins 5. Seville, January 26 to $28,2000$.

50. Matzke GR, Zhanel GG, Guay DRP. Clinical pharmacokinetics of vancomycin. Clin Pharmacokin 1986;11:257-82.

51. Welshman IR, Stalker DJ, Wajszczuk CP. Assessment of absolute bioavailability and the evaluation of the effect of food on oral bioavailability of linezolid. Antiinfect Drugs Chemother 1998;16:5-9.

52. Pawsey S, Daley-Yates PT, Wajszczuk CP. U-100766 safety, toleration and pharmacokinetics after oral and intravenous administration. 1st European Congress on Chemotherapy, Glasgow, March 11 to 15, 1996. (Abst)

53. Pharmacia and Upjohn. Data on File. Kalamazoo, Michigan, 2000.

54. Wienkers LC, Wynalda MA, Feenstra KL. In vitro metabolism of linezolid (PNU-100766): Lack of induction or inhibition of cytochrom P450 enzymes and studies on the mechanism of formation of the major human metabolite PNU-142586. 39 th Interscience Conference on Antimicrobial Agents and Chemotherapy. San Francisco, September 26 to 29, 1999.

55. Feenstra K, Slatter JG, Stalker DJ, et al. Metabolism and excretion of the oxazolidinone antibiotic linezolid (PNU-100766) following oral administration of [14-C]PNU-100766 to healthy human volunteers. 38th Interscience Conference on Antimicrobial Agents and Chemotherapy. San Diego, September 24 to 27, 1998. (Abst)

56. Sisson TA, Jungbluth GL, Hopkins N. Effect of age and gender on linezolid pharmacokinetics. International Conference on Macrolildes, Azalides, and Streptogramins 5. Seville, January 26 to $28,2000$.

57. Craig W. Choosing an antibiotic on the basis of pharmacodynamics. ENT J 1998;77(Suppl 6):7-11.

58. Nightingale C. Pharmcokinetics and pharmacodynamics of newer macrolides. Pediatr Infect Dis 1997;16:438-43.

59. Craig W. Pharmacokinetic/pharmacodynamic parameters: rationale for antibacterial dosing of mice and men. Clin Infect Dis 1998;26:1-10

60. Zhanel G, Craig WA. Pharmacokinetic contributions to postantibiotic effects: focus on aminoglycosides. Clinical Pharmacokinet 1994;27:377-92.

61. Zhanel G, Waltky A, Vercaigne L, et al. The new fluoroquinolones: a critical review. Can J Infect Dis 1999;10:207-38.

62. Thomas J, Forrest, A, Bhaunani SM, et al. Pharmacodynamic evaluation of factors associated with the development of bacterial resistance in acutely ill patients during therapy. Antimicrob Agents Chemother 1998;42:521-7.

63. Forrest A, Nix DE, Ballow CH. Pharmacodynamics of intravenous ciprofloxacin in seriously ill patients. Antimicrob Agents Chemother 1993:37:1073-81

64. Andes D, Van Ogtrop ML, Craig WA. Pharmacodynamic activity of a new oxazolidinone, linezolid, in an animal infection model. 38th Interscience Conference on Antimicrobial Agents and Chemotherapy. San Diego, September 24 to 27, 1998. (Abst)

65. Bostic GD, Perri MB, Thal LA, Zervos MJ. Comparative in vitro and bactericidal activity of oxazolidinone antibiotics against multidrug resistant enterococci. Diagn Microbiol Infect Dis 1998;30:109-12.

66. Gemell C, Ford, CW. Expression of virulence factors by Grampositive cocci exposed to sub-MIC levels of linezolid. 39th Interscience Conference on Antimicrobial Agents and Chemotherapy. San Francisco, September 26 to 29, 1999 (Abst B118)

67. Stevens DL SL, Bruss JB. Randomized comparison of linezolid (PNU-100766) versus oxacillin-dicloxacillin for treatment of complicated skin and soft tissue infections. Antimicrob Agents Chemother 2000;44:3408-13.

68. Cammarata SK, San Pedro GS, Timm JA, et al. Comparison of linezolid versus ceftriaxone/cefpodoxime in the treatment of hospitalized patients with community-acquired pneumonia. European Conference on Clinical Microbiology and Infectious Diseases. Stockholm, May 28 to 31, 2000.

69. Cammarata SK, Nahass R, Todd WM, Oliphant TH, Hafkin B. Linezolid is effective against penicillin-resistant Streptococcus pneumoniae (PRSP) in hospitalized patients with communityacquired pneumonia. European Conference on Clinical Microbiology and Infectious Diseases. Stockholm, Sweden, May 28 to 31, 2000.

70. Cammarata SK, Echevarria J, Fabian G, Pineiro A, Kempsall KA, Timm JA. Linezolid in the treatment of community-acquired pneumonia: The results of phase II and phase III studies. Ninth International Congress on Infectious Diseases. Buenos Aires, April 10 to $13,2000$.

71. Cammarata SK, Timm JA, Hempsall KA, Todd WM, Oliphant TH, Hafkin B. Efficacy of linezolid in pneumonia due to penicillin intermediate and resistant Streptococcus pneumoniae. Ninth International Congress on Infectious Diseases. Buenos Aires, April 10 to 13, 2000.

72. Leach TS, Cammarata SK, Hempsall KA, Timm JA, Kaja RW, Eckert SE. Linezolid for the treatment of community- or hospitalacquired pneumonia caused by Staphylococcus aureus: results of four randomized phase III trials, Ninth International Congress on Infectious Diseases. Buenos Aires, April 10 to 13, 2000.

73. Molinari MP, Garrera GM, Pimm MHJ, DeCian W, Aronkyto T, Gomez H. Linezolid in the treatment of outpatients with community acquired pneumonia: European results. European Conference on Clinical Microbiology and Infectious Diseases. Stockholm, May 28 to $31,2000$.

74. Rubinstein E, Cammarata SK, Oliphant TH, Wunderdink RG and the Linezolid Nosocomial Pneumonia Study Group. Linezolid (PNU-100766) versus vancomycin in the treatment of hospitalized patients with nosocomial pneumonia: A randomized double-blind multicentre study. Clin Infect Dis 2001;32:402-12.

75. Duvall SE, Seas C, Bruss JB, McConnell-Martin MA, Todd WM, Hafkin B. Comparison of linezolid to oral clarithromycin in the treatment of uncomplicated skin infections: Results from a multinational phase III Trial. Ninth International Congress on Infectious Diseases. Buenos Aires, April 10 to 13, 2000.

76. Stevens DL, Smith LG, Bruss JB, et al. Randomized comparison of linezolid (PNU-100766) versus oxacillin-dicloxacillin for treatment of complicated skin and soft-tissue infections. Antimicrob Agents Chemother 2000;44:3408-13.

77. Bruss JB, Prieto M, Duvall SE, McConnell-Martin MA, Todd WM, Hafkin B. Linezolid in the treatment of cellulitus and erysipelas: combined results from four phase III multinational clinical trials. Ninth International Congress on Infectious Diseases. Buenos Aires, April 10 to 13,2000 .

78. Li Z, Willke RJ, Pinto LA, Rittenhouse BE, et al. Comparison of length of hospital stay for patients known or suspected methicillinresistant Staphylococus species infections treated with linezolid or vancomycin: A randomized multicentre trial. Pharmacother 2001;21:263-74

79. Wilkes N, McConnell-Martin, Oliphant TH, Batts DH. Safety and tolerance of linezolid in phase II trials. International Conference on Macrolildes, Azalides, and Streptogramins 5. Seville, January 26 to 28,2000 .

80. Birmingham MC, Zimmer GS, Hafkin B, et al. Outcomes with linezolid (lzd) from an ongoing compassionate use (cu) trial of patients (pts) with significant, resistant, Gram-positive infections. 40th Interscience Conference on Antimicrobial Agents and Chemotherapy, Toronto, September 17 to 20, 2000.

81. Bruss JB, Smith LG, Duvall SE, et al. Safety and tolerance of linezolid: adverse events reported in phase III trials. 40th Interscience Conference on Antimicrobial Agents and Chemotherapy, Toronto, September 17 to $20,2000$.

82. Pharmacia and Upjohn. Linezolid (Zyvox) product monograph. Pharmacia and Upjohn Company. Kalamazzo, Michigan, 2000.

83. Martin JP, Herberg JT, Slatter JG, Dupuis MJ. Although a novel microtiter-plate assay demonstrates that linezolid (PNU-100766) is a weak, competitive reversible) inhibitor of human monoamine oxidase (MAO A), no clinical evidence of MAO A inhibition in clinical trials has been observed. 38th Interscience Conference on Antimicrobial Agents and Chemotherapy. San Diego, September 24 to $27,1998$.

84. Willke RJ, Li ZJ, Rittenhouse BE, et al. Linezolids effects on early hospital discharge in hospitalized patients with complicated skin and soft tissue infections (CSSTI) under varying rates of methicillinresistant staphylococcus (MRS) infection: analysis of results from two randomized clinical trials (RCTs). 40th Interscience Conference on Antimicrobial Agents and Chemotherapy. Toronto, September 17 to 20,2000 .

85. Gonzales RD, Schreckenberger PC, Graham MB, Kelkar S, DenBesten K, Quinn JP. Infections due to vancomycin resistant Enterococcus faecium resistant to linezolid. Lancet $2001 ; 357: 1179$ 


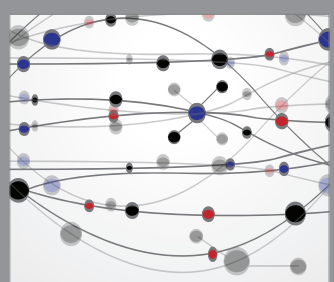

The Scientific World Journal
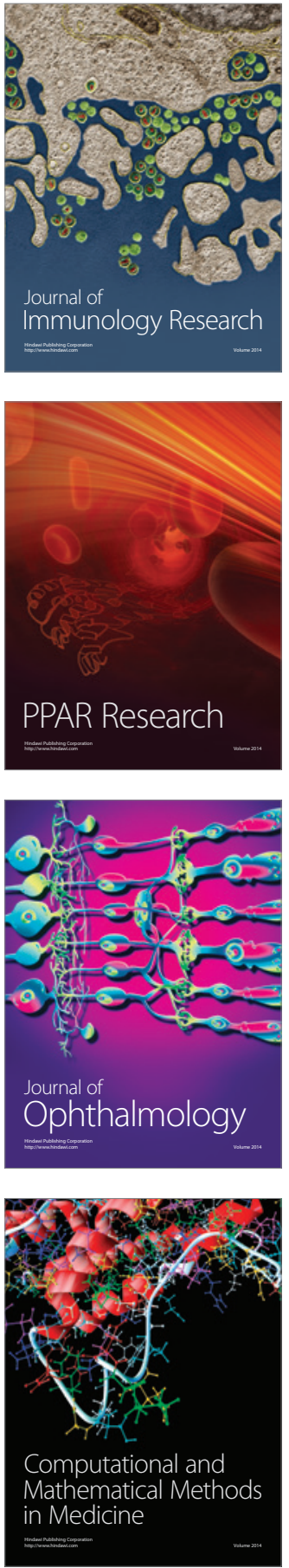

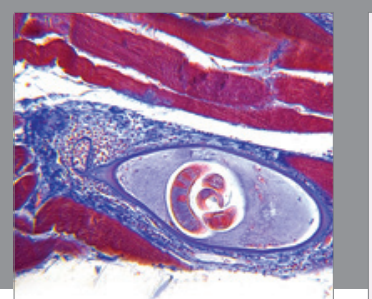

Gastroenterology Research and Practice

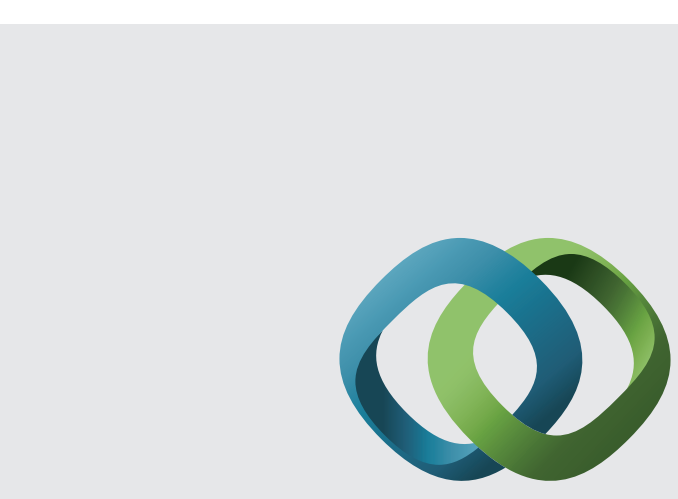

\section{Hindawi}

Submit your manuscripts at

http://www.hindawi.com
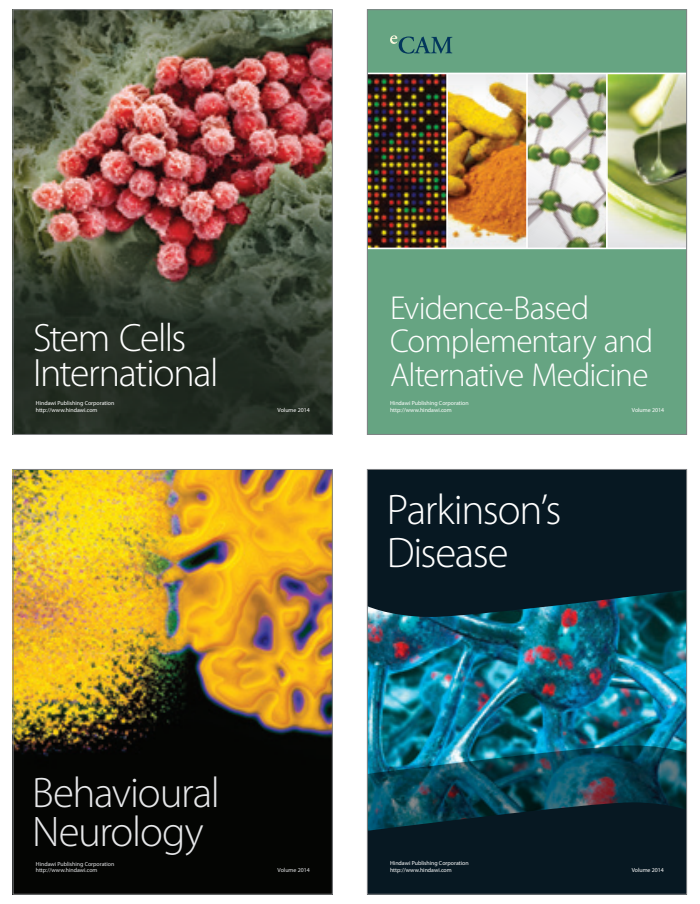
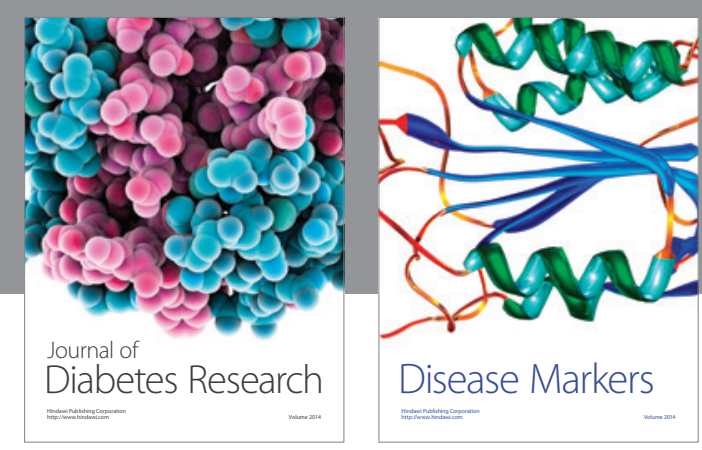

Disease Markers
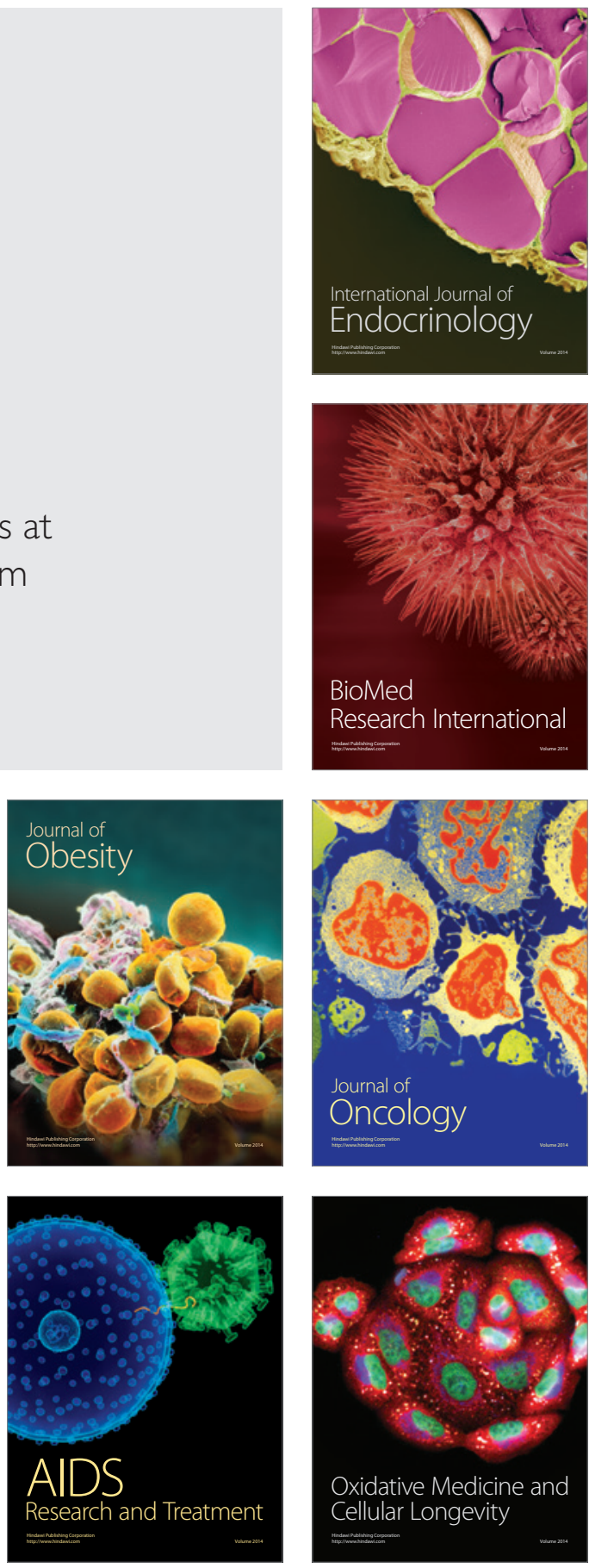